\title{
A Novel Heteroditopic Terpyridine-Pincer Ligand as Building Block for Mono- and Heterometallic $\mathrm{Pd}(\mathrm{II})$ and $\mathrm{Ru}(\mathrm{II})$ Complexes
}

\author{
Marcella Gagliardo, ${ }^{\dagger}$ Gema Rodríguez, ${ }^{\dagger}$ Henk H. Dam, ${ }^{\dagger}$ Martin Lutz," Anthony L. Spek, ${ }^{\|, \S}$ \\ Remco W. A. Havenith,,$+\neq$ Paolo Coppo, ${ }^{+}$Luisa De Cola, ${ }^{+, \perp}$ František Hartl, ${ }^{+}$ \\ Gerard P. M. van Klink, ${ }^{\dagger}$ and Gerard van Koten ${ }^{*, \dagger}$ \\ Debye Institute, Organic Chemistry and Catalysis, Padualaan 8, \\ 3584 CH Utrecht, The Netherlands, Bijvoet Center for Biomolecular Research, Crystal and \\ Structural Chemistry, Padualaan 8, 3584 CH Utrecht, The Netherlands, Debye Institute, \\ Theoretical Chemistry Group, Padualaan 8, 3584 CH Utrecht, The Netherlands, and Van't Hoff \\ Institute for Molecular Sciences, Molecular Photonic Materials, University of Amsterdam, \\ Nieuwe Achtergracht 166, 1018 WV Amsterdam, The Netherlands
}

Received November 14, 2005

A palladium-catalyzed Stille coupling reaction was employed as a versatile method for the synthesis of a novel terpyridine-pincer (3, TPBr) bridging ligand, 4'- $\left\{4-\mathrm{BrC}_{6} \mathrm{H}_{2}\left(\mathrm{CH}_{2} \mathrm{NMe}_{2}\right)_{2}-3,5\right\}-2,2^{\prime}: 6^{\prime}, 2^{\prime \prime}$-terpyridine. Mononuclear species $[\mathrm{PdX}(\mathrm{TP})](\mathrm{X}=\mathrm{Br}, \mathrm{Cl}),[\mathrm{Ru}(\mathrm{TPBr})(\mathrm{tpy})]\left(\mathrm{PF}_{6}\right)_{2}$, and $\left[\mathrm{Ru}\left(\mathrm{TPBr}_{2}\right)_{2}\right]\left(\mathrm{PF}_{6}\right)_{2}$, synthesized by selective metalation of the NCNBr-pincer moiety or complexation of the terpyridine of the bifunctional ligand $\mathrm{TPBr}$, were used as building blocks for the preparation of heterodi- and trimetallic complexes $[\mathrm{Ru}(\mathrm{TPPdCl})(\mathrm{tpy})]\left(\mathrm{PF}_{6}\right)_{2}(7)$ and $\left[\mathrm{Ru}(\mathrm{TPPdCl})_{2}\right]-$ $\left(\mathrm{PF}_{6}\right)_{2}$ (8). The molecular structures in the solid state of $[\mathrm{PdBr}(\mathrm{TP})](4 \mathrm{a})$ and $\left[\mathrm{Ru}(\mathrm{TPBr})_{2}\right]\left(\mathrm{PF}_{6}\right)_{2}(6)$ have been determined by single-crystal X-ray analysis. Electrochemical behavior and photophysical properties of the monoand heterometallic complexes are described. All the above di- and trimetallic Ru complexes exhibit absorption bands attributable to ${ }^{1} \mathrm{MLCT}$ (Ru $\rightarrow$ tpy) transitions. For the heteroleptic complexes, the transitions involving the unsubstituted tpy ligand are at a lower energy than the tpy moiety of the TPBr ligand. The absorption bands observed in the electronic spectra for $\mathrm{TPBr}$ and $[\mathrm{PdCl}(\mathrm{TP})]$ have been assigned with the aid of TD-DFT calculations. All complexes display weak emission both at room temperature and in a butyronitrile glass at $77 \mathrm{~K}$. The considerable red shift of the emission maxima relative to the signal of the reference compound $\left[\mathrm{Ru}(\mathrm{tpy})_{2}\right]^{2+}$ indicates stabilization of the luminescent ${ }^{3} \mathrm{MLCT}$ state. For the mono- and heterometallic complexes, electrochemical and spectroscopic studies (electronic absorption and emission spectra and luminescence lifetimes recorded at room temperature and $77 \mathrm{~K}$ in nitrile solvents), together with the information gained from IR spectroelectrochemical studies of the dimetallic complex $\left[\mathrm{Ru}(\mathrm{TPPdSCN})\left(\mathrm{tpy}_{\mathrm{p}}\right)\right]\left(\mathrm{PF}_{6}\right)_{2}$, are indicative of charge redistribution through the bridging ligand $\mathrm{TPBr}$. The results are in line with a weak coupling between the $\left\{\mathrm{Ru}(\mathrm{tpy})_{2}\right\}$ chromophoric unit and the (non)metalated NCNpincer moiety.

\section{Introduction}

In the past decade, attention has been focused considerably on photoinduced electron- and energy-transfer processes in

* To whom correspondence should be addressed. E-mail: g.vankoten@chem.uu.nl. Fax: 31-30-252-3615. Tel: 31-30-253-3120.

$\dagger$ Debye Institute, Organic Chemistry and Catalysis.

"Bijvoet Center for Biomolecular Research, Crystal and Structural Chemistry.

$\S$ To whom crystallographic inquiries may be directed. E-mail: a.1.spek@chem.uu.nl.

\# Debye Institute, Theoretical Chemistry Group. (This group is affiliated with Organic Chemistry and Catalysis.)

Address correspondence pertaining to theoretical calculations to this author. E-mail: r.w.a.havenith@chem.uu.nl.

+ Van't Hoff Institute for Molecular Sciences.

${ }^{\perp}$ Present address: Physikalisches Institut, Westfälische WilhelmsUniversität Münster, Mendelstrasse 7, 48149 Münster, Germany.

10.1021/ic051967c CCC: $\$ 33.50$ (c) 2006 American Chemical Society Published on Web 02/09/2006 multimetallic complexes between $\mathrm{Ru}$ - and Os - polypyridine chromophores communicating through a wide range of linear bridging ligands. ${ }^{1}$ Recent developments have highlighted many possibilities resulting from the incorporation of transition metals in multifunctional assemblies covalently attached to soft chromophoric centers. ${ }^{2}$ A fascinating field of study is emerging on molecular architectures with unique photochemical and electrochemical properties aimed at energy conversion, photonic and electronic devices, and biomedical applications. ${ }^{3}$ Metallosupramolecular structures based on (hetero)ditopic linear bridging ligands, prepared via the introduction of functionalities at the $4^{\prime}$-position of a terpyridine moiety, play a major role in this field. The possibility of building systems assembled in a topologically controlled

Inorganic Chemistry, Vol. 45, No. 5, 20062143 
Gagliardo et al.

Scheme 1. Synthesis of TPBr Ligand (3) ${ }^{a}$

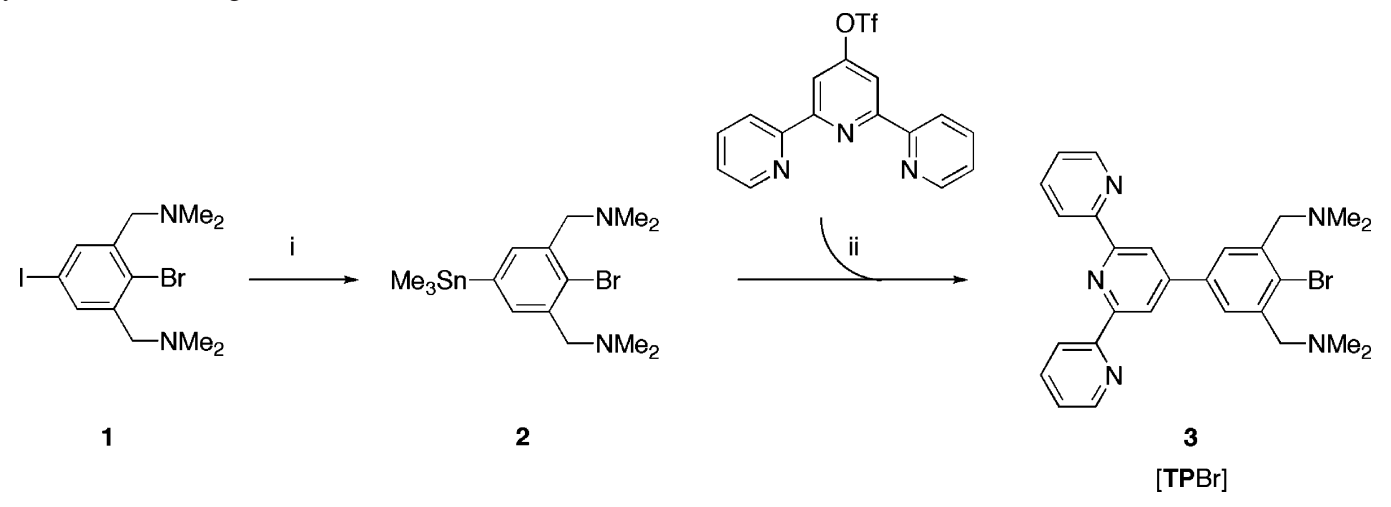

${ }^{a}$ Reagents and conditions: (i) (a) two equivalents of $t \mathrm{BuLi}, \mathrm{Et}_{2} \mathrm{O},-100^{\circ} \mathrm{C}, 0.5 \mathrm{~h}$; (b) $\mathrm{Me}_{3} \mathrm{SnCl}_{1} \mathrm{Et}_{2} \mathrm{O},-100{ }^{\circ} \mathrm{C} \rightarrow \mathrm{RT}, 15 \mathrm{~h}$. (ii) $\mathrm{LiCl},\left[\mathrm{PdCl}_{2}\left(\mathrm{PPh}_{3}\right)_{2}\right]$,
toluene, reflux, $20 \mathrm{~h}$.

fashion, in which donor and acceptor components are situated in opposite directions, makes the use of terpyridine units attractive. ${ }^{4}$ The structural advantages of terpyridine-type complexes are, however, offset by their less-favorable photophysical properties. ${ }^{1}$ For example, $\left[\mathrm{Ru}\left(\mathrm{tpy}_{2}\right)\right]^{2+}$ compounds have short-lived excited states and thus display a very weak emission at room temperature. ${ }^{5}$ A significant increase in the luminescence lifetime can be achieved by a proper functionalization of terpyridine ligands at the $4^{\prime}$-position. ${ }^{\mathrm{b} b \mathrm{i}, \mathrm{6}}$

However, insertion of organometallic subunits containing a metal-carbon $\sigma$-bond in such species is still relatively

(1) (a) Sauvage, J.-P.; Collin, J.-P.; Chambron, J.-C.; Guillerez, S.; Coudret, C.; Balzani, V.; Barigelletti, F.; De Cola, L.; Flamigni, L. Chem. Rev. 1994, 94, 993. (b) Maestri, M.; Armaroli, N.; Balzani, V.; Constable, E. C.; Cargill Thompson, A. M. W. Inorg. Chem. 1995, 34, 2759. (c) Harriman, A.; Ziessel, R. Chem. Commun. 1996, 1707. (d) Constable, E. C. In Electronic Materials: The Oligomer Approach; Wiley-VCH: Weinheim, Germany, 1998. (e) Schwab, P. F. H.; Levin, M. D.; Michl, J. Chem. Rev. 1999, 99, 1863. (f) Barigelletti, F.; Flamigni, L. Chem. Soc. Rev. 2000, 29, 1. (g) Padilla-Tosta, M. E.; Lloris, J. M.; Martínez-Máñez, R.; Benito, A.; Soto, J.; Pardo, T.; Miranda, M. A.; Markos, M. D. Eur. J. Inorg. Chem. 2000, 741. (h) Constable, E. C.; Housecroft, C. E.; Johnston, L. A.; Armspach, D.; Neuburger, M.; Zehnder, M. Polyhedron 2001, 20, 483. (i) Wang, J.; Hanan, G. S.; Loiseau, F.; Campagna, S. Chem. Commun. 2004, 2068. (j) Barbieri, A.; Ventura, B.; Barigelletti, F.; De Nicola, M. Q.; Ziessel, R. Inorg. Chem. 2004, 43, 7359. (k) Constable, E. C.; Figgemeier, E.; Housecroft, C. E.; Olsson, J.; Zimmermann, Y. C. J. Chem. Soc., Dalton Trans. 2004, 1918. (1) Jukes, R. T. F.; Adamo, V.; Hartl, F.; Belser, P.; De Cola, L. Coord. Chem. Rev. 2005, 249, 1327.

(2) (a) Howard, C. A.; Ward, M. D. Angew. Chem., Int. Ed. 1992, 31, 1028. (b) Constable, E. C.; Housecroft, C. E.; Neuburger, M.; Schneider, A. G.; Zehnder, M. J. Chem. Soc., Dalton Trans. 1997, 2427. (c) Pickaert, G.; Cesario, M.; Douce, L.; Ziessel, R. Chem. Commun. 2002, 1125. (d) Constable, E. C.; Housecroft, C. E.; Neuburger, M.; Schneider, A. G.; Springler, B.; Zehnder, M. Inorg. Chim. Acta 2000, 300-302, 49. (e) Wang, P.; Zakeeruddin, S. M.; Moser, J. E.; Nazeeruddin, M. K.; Sekiguchi, T.; Grätzel, M. Nat. Mater. 2003, 2, 402. (f) Fujihara, T.; Okamura, R.; Wada, T.; Tanaka, K. J. Chem. Soc., Dalton Trans. 2003, 3221. (g) Polo, A. S.; Itokazu, M. K.; Iha, Y. M. Coord. Chem. Rev. 2004, 248, 1343. (h) Okamura, R.; Wada, T.; Aikawa, K.; Nagata, T.; Tanaka, K. Inorg. Chem. 2004, 43, 7210.

(3) (a) Collin, J.-P.; Graviña, P.; Heitz, V.; Sauvage, J.-P. Eur. J. Inorg. Chem. 1998, 1. (b) Akasaka, T.; Otsuki, J.; Araki, K. Chem.-Eur. J. 2002, 8, 131. (c) Dattelbaum, D. M.; Hartshorn, C. M.; Meyer, T. J. J. Am. Chem. Soc. 2002, 124, 4938. (d) Encinas, S.; Flamigni, L.; Barigelletti, F.; Constable, E. C.; Housecroft, C. E.; Schonfield, E. R.; Figgemeier, E.; Fenske, D.; Neuburger, M.; Vos, J. G.; Zehnder, M. Chem.-Eur. J. 2002, 8, 137. (e) Harriman, A.; Khatyr, A.; Ziessel, R. J. Chem. Soc., Dalton Trans. 2003, 2061. (f) Harriman, A.; Hissler, M.; Khatyr, A.; Ziessel, R. Eur. J. Inorg. Chem. 2003, 955. (g) Fallahpour, R.-A. Synthesis 2003, 2, 155. (h) van der Schilden, K.; Garcìa, F.; Kooijman, H.; Spek, A. L.; Haasnoot, J. G.; Reedijk, J. Angew. Chem., Int. Ed. 2004, 43, 5668.

unexplored. ${ }^{7}$ Organometallic components incorporated into supramolecular architectures, with the influence of other tunable building blocks, are expected to exhibit reactivity patterns quite different from those of their mononuclear counterparts. ${ }^{7}$ For example, recent results published by Inagaki and co-workers demonstrated that dinuclear $\mathrm{Ru}-\mathrm{Pd}$ species $\left[(\mathrm{bpy})_{2} \mathrm{Ru}(\mu \text {-bmp }) \operatorname{Pd}(\mathrm{Me})\left(\mathrm{Me}_{2} \mathrm{CO}\right)\right]^{3+}$ and $\left[(\mathrm{bpy})_{2} \mathrm{Ru}(\mu\right.$-bmp) $\operatorname{Pd}(\mathrm{Me})(\mathrm{MeCN})]^{3+}\left(\mathrm{bmp}=2,2^{\prime}\right.$-bipyrimidine $)$, containing a photosensitizing $\mathrm{Ru}^{\mathrm{II}}$ unit and a reactive $\mathrm{Pd}$ center, catalyzed selective dimerization of $\alpha$-methylstyrene to give 2,4-diphenyl-4-methyl-1-pentene under irradiation with visible light. ${ }^{8}$

The ability of the monoanionic, terdentate-coordinating pincer ligands to give stable cyclometalated complexes, which can be applied as catalysts in various organic transformations ${ }^{9}$ or in the construction of materials ${ }^{10}$ (e.g., liquid crystalline materials and optical and electrooptical devices), prompted us to investigate molecular assemblies on the basis of the novel heteroditopic terpyridine-pincer ligand 4'- $\left\{4-\mathrm{BrC}_{6} \mathrm{H}_{2}\left(\mathrm{CH}_{2} \mathrm{NMe}_{2}\right)_{2}-3,5\right\}-2,2^{\prime}: 6^{\prime}, 2^{\prime \prime}$-terpyridine (TPBr (3); Scheme 1). In light of the rich coordination chemistry of both the terpyridine ${ }^{1-3}$ and the $\mathrm{NCN}-$ aryl pincer moieties ${ }^{11}$ the TPBr ligand is envisaged as a valuable building block for construction of metallo-supramolecular polymers ${ }^{12}$ and decoration of dendritic wedges ${ }^{13}$ that incorporate catalytically active fragments and photosensitizing $\mathrm{Ru}^{\mathrm{II}}$-tpy moieties.

Here, the synthesis of the novel ligand $\mathbf{T P B r}$ and the first examples of its coordination chemistry are presented. The dual reactivity of TPBr permits the synthesis of monometallic complexes bearing externally directed vacant binding sites. These species can further be used as building blocks for the preparation of heterometallic complexes via stepwise syn-

(4) (a) Sauvage, J.-P.; Ward, M. Inorg. Chem. 1991, 30, 3869. (b) von Zelensky, A. In Stereochemistry of Coordination Compounds; Wiley: Chichester, U.K., 1996. (c) Hofmeier, H.; Schubert, U. S. Chem. Soc. Rev. 2004, 33, 373.

(5) (a) Hissel, M.; El-Ghayoury, A.; Harriman, A.; Ziessel, R. Angew. Chem., Int. Ed. 1998, 37, 1717. (b) Winkler, J. R.; Netzel, T. L.; Crentz, C.; Sutin, N. J. Am. Chem. Soc. 1987, 109, 2381.

(6) Medlycott, E. A.; Hannan, G. S. Chem. Soc. Rev. 2005, 43, 133.

(7) Yam, V. W. W.; Lee, W. W.; Cheung, K. K. Organometallics 1997, $16,2833$.

(8) Inagaki, A.; Edure, S.; Yatsuda, S.; Akita, M. Chem. Commun. 2005, 5486. 
Scheme 2. Synthesis of Homometallic Complexes $\mathbf{4 b}, \mathbf{5}$, and $\mathbf{6}^{a}$

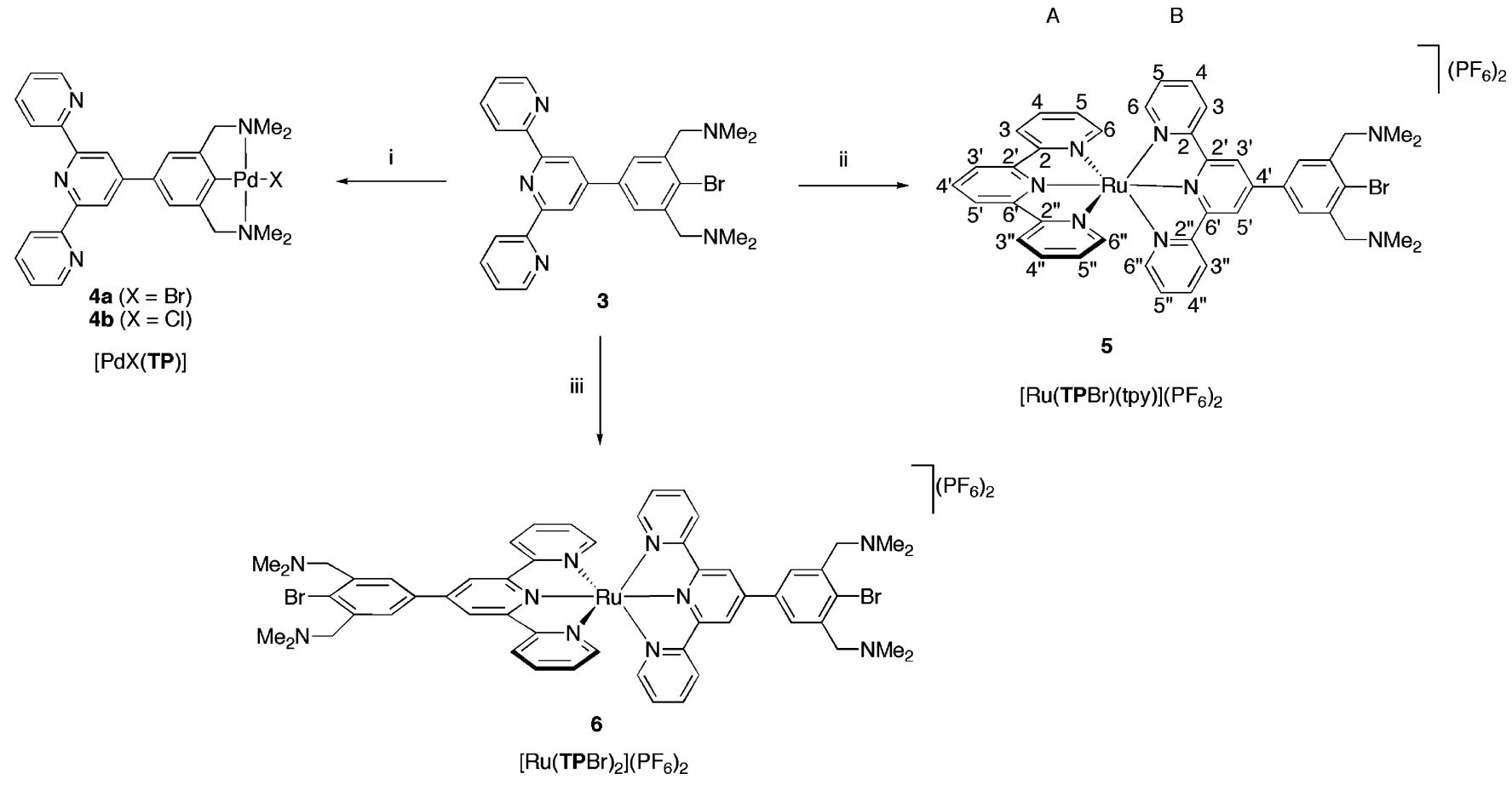

${ }^{a}$ Reagents and conditions: (i) (a) 0.5 equiv of $\left[\mathrm{Pd}_{2}(\mathrm{dba})_{3}\right] \cdot \mathrm{CHCl}_{3}, \mathrm{C}_{6} \mathrm{H}_{6}$, reflux, $2 \mathrm{~h}$; (b) $\mathrm{Me}_{3} \mathrm{SiOTf}_{1} \mathrm{CH}_{2} \mathrm{Cl}_{2}$; (c) $\mathrm{NaCl}$, acetone. (ii) (a) [RuCl (tpy)], $\mathrm{N}$-ethylmorpholine, $\mathrm{MeOH}$, reflux, $1 \mathrm{~h}$; (b) $\mathrm{NaPF}_{6}, \mathrm{MeOH}$. (iii) (a) 0.5 equiv of $\mathrm{RuCl}_{3} \cdot 3 \mathrm{H}_{2} \mathrm{O}, \mathrm{Et}_{3} \mathrm{~N}, \mathrm{EtOH}$, reflux, $1 \mathrm{~h}$; (b) $\mathrm{NaPF} 6, \mathrm{MeOH}$

theses, using the "complex-as-ligand" approach. ${ }^{2 a}$ In addition, for a deeper understanding of the nature of the intercomponent electronic coupling between the metal centers through the bridging ligand in the synthesized heterodi- and trimetallic species, we have applied electrochemical, spectroelectrochemical, and photophysical methods.

\section{Results and Discussion}

Synthesis of the Heteroditopic Ligand [TPBr]. Attempts to prepare the heteroditopic ligand $4^{\prime}-\left\{\mathrm{BrC}_{6} \mathrm{H}_{2}\left(\mathrm{CH}_{2} \mathrm{NMe}_{2}\right)_{2}-\right.$ 2,6\}-2,2':6',2' -terpyridine (TPBr, (3), Scheme 1) by applying the Kröhnke methodology ${ }^{14}$ gave a mixture of different compounds, from which the desired product could not be isolated by standard procedures. Application of a $\mathrm{Pd}$ catalyzed Stille cross-coupling ${ }^{15}$ proved to be a facile onestep synthetic pathway toward $\mathbf{3}$. The formation of $\mathbf{3}$ was achieved by reaction of the stannane pincer compound $4^{\prime}$ $\left\{\mathrm{BrC}_{6} \mathrm{H}_{2}\left(\mathrm{CH}_{2} \mathrm{NMe}_{2}\right)_{2}-2,6\right\} \mathrm{SnMe}_{3}$ (2) with $4^{\prime}-\left(\mathrm{CF}_{3} \mathrm{SO}_{3}\right)-2,2^{\prime}$ : $6^{\prime}, 2^{\prime \prime}$-terpyridine ${ }^{16}$ (Scheme 1).

(9) (a) Albrecht, M.; van Koten, G. Angew. Chem., Int. Ed. 2001, 41, 3750. (b) van der Boom, M. E.; Milstein, D. Chem. Rev. 2003, 103, 1759. (c) Singleton, J. T Tetrahedron 2003, 59, 1837. (d) Kjellgren, J.; Sundén, H.; Szabó, K. J. J. Am. Chem. Soc. 2005, 127, 1787.

(10) (a) Donnio, B.; Bruce, D. W. In Structure and Bonding (Liquid Crystals II), Mingos, D. M. P., Ed.; Springer-Verlag: Berlin, 1999. (b) Ghedini, M.; Pucci, G.; Crispini, A.; Aiello, I.; Barigelletti, F.; Gessi, A.; Francescangeli, O. Appl. Organomet. Chem. 1999, 13, 565. (c) Espinet, P.; Garcìa-Orodea, E.; Miguel, J. A. Inorg. Chem. 2000, 39, 3645. (d) Omnes, L.; Timini, B. A.; Gelbrich, T.; Hursthouse, M. B.; Luckhurst, G. R.; Bruce, D. W. Chem. Commun. 2001, 2248. (e) Aiello, I.; Dattilo, D.; Ghedini, M.; Bruno, A.; Termine, R.; Golemme, A. Adv. Mater. 2002, 14, 1233. (f) Talarico, M.; Barberio, G.; Pucci, D.; Ghedini, M.; Golemme, A. Adv. Mater. 2003, 15, 1374. (g) van der Boom, M. E.; Milstein, D. Chem. Rev. 2003, 103, 1759. (h) Gagliardo, M.; Dijkstra, H. P.; Coppo, P.; De Cola, L.; Lutz, M.; Spek, A. L.; van Klink, G. P. M.; van Koten, G. Organometallics 2004, 23, 5833.
Synthesis of Monometallic Pd and Ru Complexes. Monometalated complexes 4a ([PdBr(TP)]), 5 ([Ru(TPBr)(tpy) $\left.]\left(\mathrm{PF}_{6}\right)_{2}\right)$, and $\mathbf{6}\left(\left[\mathrm{Ru}(\mathbf{T P B r})_{2}\right]\left(\mathrm{PF}_{6}\right)_{2}\right)$ were synthesized by a selective reaction of the NCNBr-pincer or tpy moiety of the heteroditopic ligand $\mathbf{3}$ with the appropriate metal precursor complex. Thus, $4 \mathbf{a}$ was prepared by the oxidative addition of palladium to the $\mathrm{C}_{\mathrm{aryl}}-\mathrm{Br}$ bond of the NCNBrpincer terminus of $\mathbf{3}$ in refluxing benzene using the $\mathrm{Pd}^{0}$ precursor $\left[\mathrm{Pd}_{2}(\mathrm{dba})_{3}\right] \cdot \mathrm{CHCl}_{3}{ }^{17}(\mathrm{dba}=$ dibenzylideneacetone $)$ (Scheme 2). Scrambling of the bromide anion in solution in the presence of chloride is expected when applying $\mathbf{4 a}$ as a building block in the synthesis of heterometallic complexes. Thus, $\mathbf{4 a}$ was converted to the chloride analogue $\mathbf{4 b}$ [TPPdCl] by bromide abstraction with $\mathrm{Me}_{3} \mathrm{SiOTf}$, followed

(11) (a) Rodríguez, G.; Albrecht, M.; Schoenmaker, J.; Lutz, M.; Spek, A. L.; van Koten, G. J. Am. Chem. Soc. 2002, 124, 5127. (b) Albrecht, M.; Lutz, M.; Spek, A. L.; van Koten, G. Nature 2000, 406, 970. (c) Slagt, M. Q.; Stiriba, S.-E.; Kautz, H.; Klein Gebbink, R. J. M.; Frey, H.; van Koten, G. Organometallics 2004, 23, 1525.

(12) (a) Lohmeijer, B. G. G.; Schubert, U. S. Angew. Chem., Ed. Int. 2002, 41, 3825. (b) Lohmeijer, B. G. G.; Schubert, U. S. J. Polym. Sci., Part A: Polym. Chem. 2003, 41, 1413. (c) Hofmeier, H.; El-Ghayoury, A.; Schenning, A. P. H. J.; Schubert, U. S. Chem. Commun. 2004, 318.

(13) (a) Constable, E. C.; Cargill Thompson, A. M. W.; Harverson, P.; Macko, L.; Zehnder, M. Chem.-Eur. J. 1995, 1, 360. (b) Serroni, S.; Campagna, S.; Puntoriero, F.; Di Pietro, C.; McClenaghan, N. D.; Loiseau, F. Chem. Soc. Rev. 2001, 30, 367.

(14) (a) Cargill Thompson, A. M. W. Coord. Chem. Rev. 1997, 160, 1. (b) Newkome, G. R.; He, E.; Moorefield, C. N. Chem. Rev. 1995, 95, 2169. (c) Cave, G. W. C.; Raston, C. L. J Chem. Soc., Perkin Trans. 1 2001, 3258. (d) Cave, G. W. C.; Raston, C. L.; Scott, J. L. Chem. Commun. 2001, 2159. (e) Jiang, H.; Lee, S. J.; Lin, W. J. Chem. Soc., Dalton Trans. 2002, 3429.

(15) Heller, M.; Schubert, U. S. J. Org. Chem. 2002, 67, 8269.

(16) Potts, K. T.; Konwar, D. J. Org. Chem. 1991, 56, 4815.

(17) Alsters, P. L.; Baesjou, P. J.; Janssen, M. D.; Kooijman, H.; SichererRoetman, A.; Spek, A. L.; van Koten, G. Organometallics 1992, 11, 4124. 
Gagliardo et al.

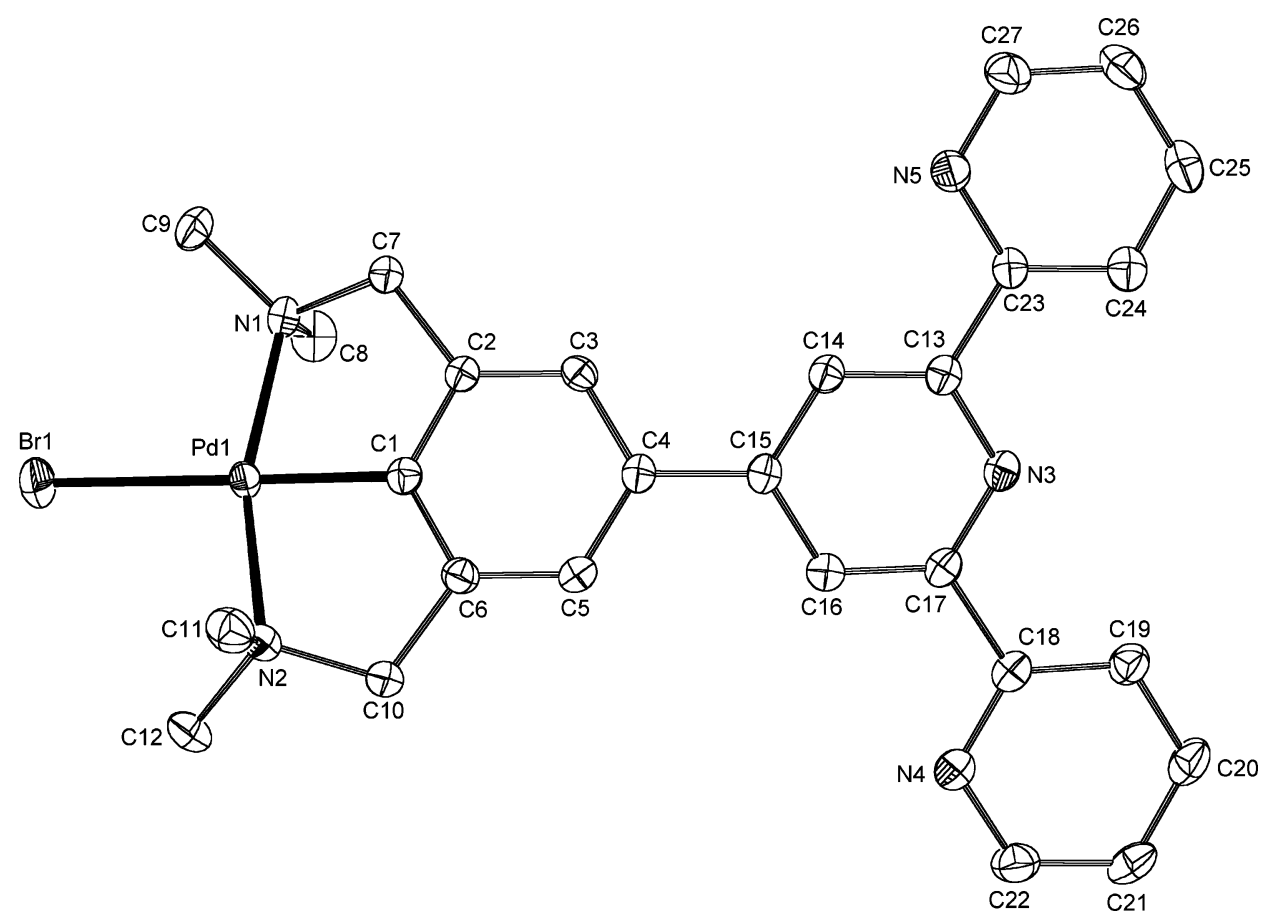

Figure 1. Displacement ellipsoid plot of complex $4 a$ (50\% probability level). Hydrogen atoms have been omitted for clarity.

by treatment with an excess of $\mathrm{NaCl}$. The structural configuration of solid 4a was obtained from a single-crystal X-ray diffraction analysis. A molecular plot of complex $\mathbf{4 a}$ is shown in Figure 1, and a selection of bond lengths, angles, and torsion angles is reported in Table 1. The $\mathrm{Pd}^{\mathrm{II}}$ center is in a

Table 1. Selected Bond Lengths ( $\mathrm{A})$, Bond Angles (deg), and Torsion Angles (deg) of Complex 4a

\begin{tabular}{lcll}
\hline \multicolumn{4}{c}{ Bond Lengths $(\AA)$} \\
Pd1-Br1 & $2.5406(3)$ & Pd1-N2 & $2.1183(19)$ \\
Pd1-C1 & $1.924(2)$ & C4-C15 & $1.485(3)$ \\
Pd1-N1 & $2.1234(19)$ & C13-C23 & $1.485(3)$ \\
\multicolumn{5}{c}{ C17-C18 } & $1.494(3)$ \\
\multicolumn{5}{c}{ Bond Angles (deg) } \\
Br1-Pd1-C1 & $176.48(6)$ & Br1-Pd1-N2 & $100.91(5)$ \\
N1-Pd1-N2 & $161.98(7)$ & C1-Pd1-N1 & $81.17(8)$ \\
Br1-Pd-N1 & $96.97(5)$ & C1-Pd1-N2 & $80.86(8)$ \\
\multicolumn{5}{c}{} \\
C3-C4-C15-C14 & Torsion Angles (deg) \\
C3-C4-C15-C16 & 23.7(3) & C16-C17-C18-N4 \\
C14-C13-C23-N5 & $-2.6(2)$ & C16-C17-C18-C19 & $-2.6(3)$ \\
C14-C13-C23-C24 & $-179.9(2)$ & C1-C2-C7-C6-C10-N2 & $-30.4(2)$ \\
& & & $-17.1(3)$
\end{tabular}

distorted square-planar environment and embedded in the terdentate coordination pocket of the NCN framework. The bond lengths in $\mathbf{4 a}$ are consistent with the values reported for other neutral $\mathrm{NCN}-\mathrm{Pd}^{\mathrm{II}}$ complexes. The three pyridine rings of the tpy moiety adopt a planar conformation, with the nitrogen atoms in adjacent rings trans with respect to each other, thereby minimizing the electrostatic repulsion between the nitrogen lone pairs and the molecular dipoles. A torsion angle of $23.7(3)^{\circ}$ for $\mathrm{C} 3-\mathrm{C} 4-\mathrm{C} 15-\mathrm{C} 14$ indicates twisting of the $\mathrm{NCN}$ and tpy moieties about the interannular $\mathrm{C} 4-\mathrm{C} 15$ bond, which is in the expected $20-40^{\circ}$ range of ortho-H biphenyl compounds.

The monometallic complex $\mathbf{5}$ was prepared by the direct reaction of $\left[\mathrm{RuCl}_{3}\right.$ (tpy)] with 3 in refluxing $\mathrm{MeOH}$ in the presence of the reducing agent $N$-ethylmorpholine. Treatment of the intensely red-colored solution with $\mathrm{NaPF}_{6}$ resulted in the precipitation of $\mathbf{5}$ as a purple-red powder. Because of the low symmetry of the compounds, assignments of the aromatic fingerprint region of the ${ }^{1} \mathrm{H}$ NMR spectrum were aided by $2 \mathrm{D}{ }^{1} \mathrm{H}-{ }^{1} \mathrm{H}$ COSY NMR spectroscopy. The most relevant features in the ${ }^{1} \mathrm{H}$ NMR spectrum are the singlet at $8.24 \mathrm{ppm}$ for the aromatic protons of the $\mathrm{NCN}$-pincer moiety, the doublet at $9.08 \mathrm{ppm}$ for $\mathrm{H}\left(3^{\prime}\right)_{\mathrm{A}}$ of the coordinated tpy, and the singlet at $9.35 \mathrm{ppm}$ for $\mathrm{H}\left(3^{\prime}\right)_{\mathrm{B}}$ of the coordinated tpy moiety of ligand $\mathbf{3}$.

The reaction of equimolar amounts of ligand $\mathbf{3}$ and $\mathrm{RuCl}_{3}$. $3 \mathrm{H}_{2} \mathrm{O}$ in EtOH produced the intermediate building block $\left[\mathrm{RuCl}_{3}(\mathrm{TPBr})\right]$, which was isolated and subsequently treated with a second equivalent of ligand $\mathbf{3}$ in refluxing $\mathrm{MeOH}$ in the presence of the reducing agent $\mathrm{N}$-ethylmorpholine. The resulting red methanolic solution was reacted with $\mathrm{NaPF}_{6}$ to give the ruthenium complex $\left[\mathrm{Ru}(\mathbf{T P B r})_{2}\right]\left(\mathrm{PF}_{6}\right)_{2}(\mathbf{6}$, Scheme 2). Protonation of the $\mathrm{NMe}_{2}$ groups of the $\mathrm{NCN}$-pincer moieties by the acid formed during the reaction was circumvented by the addition of $\mathrm{Et}_{3} \mathrm{~N}$ to the reaction mixture. Because of the symmetry of the molecule, only eight resonances are observed in the ${ }^{1} \mathrm{H}$ NMR spectrum of complex 6. In the aliphatic region, two singlets are present for the $\mathrm{NMe}_{2}$ protons (2.39 ppm) and the benzylic $\mathrm{CH}_{2}$ groups (3.76 $\mathrm{ppm})$ of the $\mathrm{NCN}$-pincer moieties. In the aromatic region, only six peaks are observed; five of them are attributed to the tpy and the remaining one is assigned to the aromatic protons of the NCN-pincer moiety.

Single crystals of complex $\mathbf{6}$ suitable for X-ray diffraction analysis were obtained by the slow diffusion of $\mathrm{Et}_{2} \mathrm{O}$ into a $\mathrm{MeCN}$ solution of $\mathbf{6}$. Figure 2 depicts a molecular plot of $\mathbf{6}$. A selection of bond lengths, bond angles, and torsion angles is given in Table 2. The crystal structure of $\mathbf{6}$ shows the 


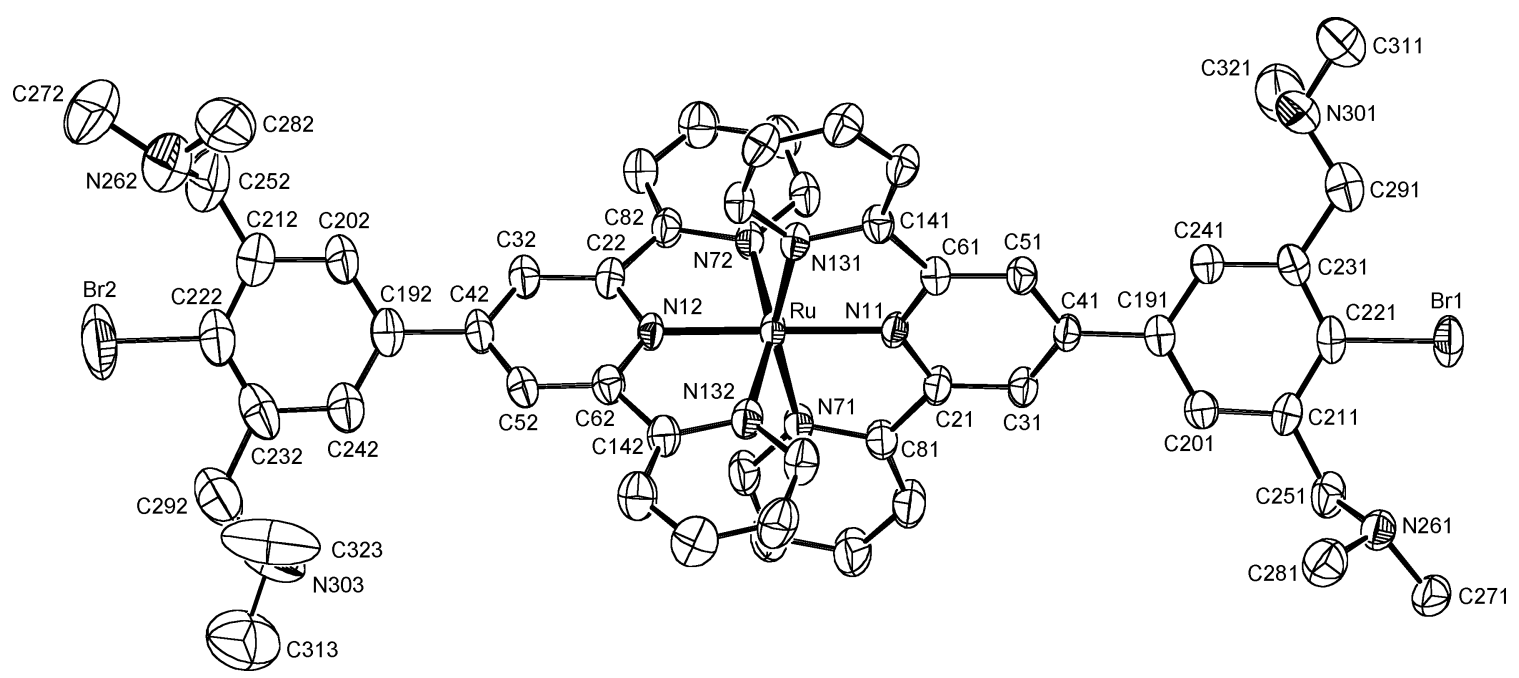

Figure 2. Displacement ellipsoid plot of cationic complex 6 (50\% probability level). Hydrogen atoms, $\mathrm{PF}_{6}$ counterions, and partially occupied acetonitrile solvent molecules have been omitted for clarity. Only one conformation of the disordered pincer arm at C292 is shown.

Table 2. Selected Bond Lengths $(\AA)$, Bond Angles (deg), and Torsion Angles (deg) of the First Independent Molecule of Complex 6

\begin{tabular}{|c|c|c|c|}
\hline \multicolumn{4}{|c|}{ Bond Lengths $(\AA)$} \\
\hline $\mathrm{Ru}-\mathrm{N} 11$ & $.965(5)$ & $\mathrm{Ru}-\mathrm{N} 131$ & $2.060(5)$ \\
\hline $\mathrm{Ru}-\mathrm{N} 12$ & $.970(5)$ & $\mathrm{Ru}-\mathrm{N} 132$ & $2.056(6)$ \\
\hline $\mathrm{Ru}-\mathrm{N} 71$ & $.065(6)$ & $\mathrm{C} 192-\mathrm{C} 42$ & $1.484(9)$ \\
\hline $\mathrm{Ru}-\mathrm{N} 72$ & $.078(6)$ & $\mathrm{C} 191-\mathrm{C} 41$ & 1.491(9) \\
\hline \multicolumn{4}{|c|}{ Bond Angles (deg) } \\
\hline $\mathrm{N} 11-\mathrm{Ru}-\mathrm{N} 12$ & $179.4(2)$ & $\mathrm{N} 71-\mathrm{Ru}-\mathrm{N} 131$ & $158.1(2)$ \\
\hline $\mathrm{N} 11-\mathrm{Ru}-\mathrm{N} 71$ & $79.2(2)$ & $\mathrm{N} 11-\mathrm{Ru}-\mathrm{N} 132$ & $101.2(2)$ \\
\hline $\mathrm{N} 11-\mathrm{Ru}-\mathrm{N} 131$ & 79.1(2) & $\mathrm{N} 11-\mathrm{Ru}-\mathrm{N} 72$ & $100.9(2)$ \\
\hline \multicolumn{4}{|c|}{ Torsion Angles (deg) } \\
\hline $\mathrm{C} 31-\mathrm{C} 21-\mathrm{C} 81-\mathrm{C} 91$ & $2.5(14)$ & C $242-\mathrm{C} 192-\mathrm{C} 42-\mathrm{C} 32$ & $2138.6(8)$ \\
\hline $\mathrm{N} 11-\mathrm{C} 21-\mathrm{C} 81-\mathrm{N} 71$ & $1.0(10)$ & C242-C192-C42-C52 & $2-39.6(12$ \\
\hline C51-C61-C141-C151 & $2.1(13)$ & C201-C191-C41-C51 & $1 \quad 150.7(7)$ \\
\hline N11-C61-C141-N131 & $1.2(9)$ & C201-C191-C41-C31 & $1-30.5(11)$ \\
\hline $\mathrm{C} 32-\mathrm{C} 22-\mathrm{C} 82-\mathrm{C} 92$ & $-0.8(13)$ & & \\
\hline $\mathrm{N} 12-\mathrm{C} 22-\mathrm{C} 82-\mathrm{N} 72$ & $-3.2(9)$ & & \\
\hline C52-C62-C142-C152 & $1.6(13)$ & & \\
\hline $\mathrm{N} 12-\mathrm{C} 62-\mathrm{C} 142-\mathrm{N} 132$ & $1.9(9)$ & & \\
\hline
\end{tabular}

ruthenium center in a distorted octahedral environment with both tpy moieties of each ligand $\mathbf{3}$ meridionally coordinated. All $\mathrm{Ru}-\mathrm{N}$ distances and internal pyridine angles are similar to those obtained for other $\mathrm{Ru}(\mathrm{II})$-tpy derivatives. ${ }^{1 \mathrm{~h}, 18}$ The tpy units are approximately planar, forming torsion angles in the range $-3.2(9)$ to $2.5(14)^{\circ}$. The torsion angles $\mathrm{C} 242-$ C192-C42-C52 and C201-C191-C41-C31 (-39.6(12) and $-30.5(11)^{\circ}$, respectively) illustrate twisting of the interannular C41-C191 and C42-C192 bonds, respectively. The edge-to-edge length of this rigid rodlike 6 is $21.735(2)$ $\AA$ for $\mathrm{Br} 1 \cdots \mathrm{Br} 2$.

Synthesis of Heterometallic Complexes. Heterometallic complexes $7\left([\mathrm{Ru}(\mathbf{T P P d C l})(\mathrm{tpy})]\left(\mathrm{PF}_{6}\right)_{2}\right)$ and $\mathbf{8}\left(\left[\mathrm{Ru}(\mathbf{T P P d C l})_{2}\right]-\right.$ $\left.\left(\mathrm{PF}_{6}\right)_{2}\right)$ were prepared from the mononuclear organometallic complex $\mathbf{4 b}$. The $\mathrm{Pd}-\mathrm{C}$ bond in $\mathbf{4 b}$ proved to be stable under the reaction conditions applied in the following synthetic steps. This stability qualifies $\mathbf{4 b}$ as an inert and versatile building block in the complex-as-ligand approach. ${ }^{2 a}$ The reaction of $\left[\mathrm{RuCl}_{3}(\right.$ tpy)$)$ with 1 equiv of $\mathbf{4} \mathbf{b}$ in $\mathrm{MeOH}$ in the

(18) (a) Beley, M.; Collin, J.-P.; Louis, R.; Metz, B.; Sauvage, J.-P. J. Am. Chem. Soc. 1991, 113, 8521. (b) Constable, E. C.; Cargill Thompson, A. M. W. New J. Chem. 1992, 16, 855.

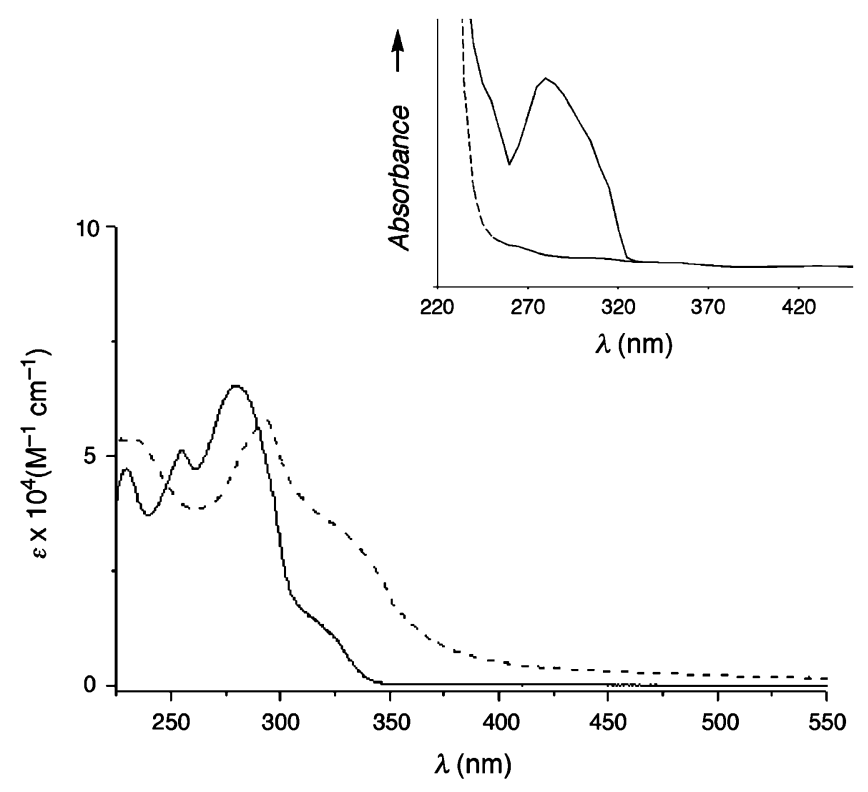

Figure 3. $\mathrm{UV}-$ vis absorption spectra of ligand $\mathbf{3}(-)$ and complex $\mathbf{4 b}$ $(---)$ measured in $\mathrm{CH}_{2} \mathrm{Cl}_{2}$ at $298 \mathrm{~K}$. Inset: $\mathrm{UV}-$ vis absorption spectra of $2,2^{\prime}: 6^{\prime}, 2^{\prime \prime}$-terpyridine $(-)$ and the pincer ligand $\left[\mathrm{BrC}_{6} \mathrm{H}_{3}\left(\mathrm{CH}_{2} \mathrm{NMe}_{2}\right)_{2}-\right.$ 2,6] (- - ) measured in $\mathrm{CH}_{2} \mathrm{Cl}_{2}$ at $298 \mathrm{~K}$.

presence of the reducing agent $N$-ethylmorpholine yielded 7 (Scheme 3). The synthesis of $\mathbf{8}$ was accomplished in a similar two-step procedure. First, $\mathbf{4 b}$ was reacted with $\mathrm{RuCl}_{3}$. $3 \mathrm{H}_{2} \mathrm{O}$ in refluxing EtOH to give the intermediate building block $\left[\mathrm{RuCl}_{3}(\mathbf{T P P d C l})\right]$ (Scheme 3 ). Subsequently, this intermediate was treated with a second equivalent of $\mathbf{4 b}$ in refluxing $\mathrm{MeOH}$ in the presence of $N$-ethylmorpholine. Coordination of the palladium center to the $\mathrm{NCNBr}$-pincer moiety prevents the protonation of the $\mathrm{NMe}_{2}$ groups by the acid formed during the reaction, thereby circumventing the need for $\mathrm{Et}_{3} \mathrm{~N}$ addition. ${ }^{1} \mathrm{H}$ NMR studies have shown that both $\mathbf{7}$ and $\mathbf{8}$ can also be prepared by the oxidative addition of palladium to the $\mathrm{C}_{\text {aryl }}-\mathrm{Br}$ bond in $\mathbf{5}$ and $\mathbf{6}$, respectively, by using the $\mathrm{Pd}^{0}$ precursor $\left[\mathrm{Pd}_{2}(\mathrm{dba})_{3}\right] \cdot \mathrm{CHCl}_{3}$ in refluxing benzene (Scheme 3). However, the extensive washing procedures required to remove liberated dba lowers the yield of this route considerably. 
Gagliardo et al.

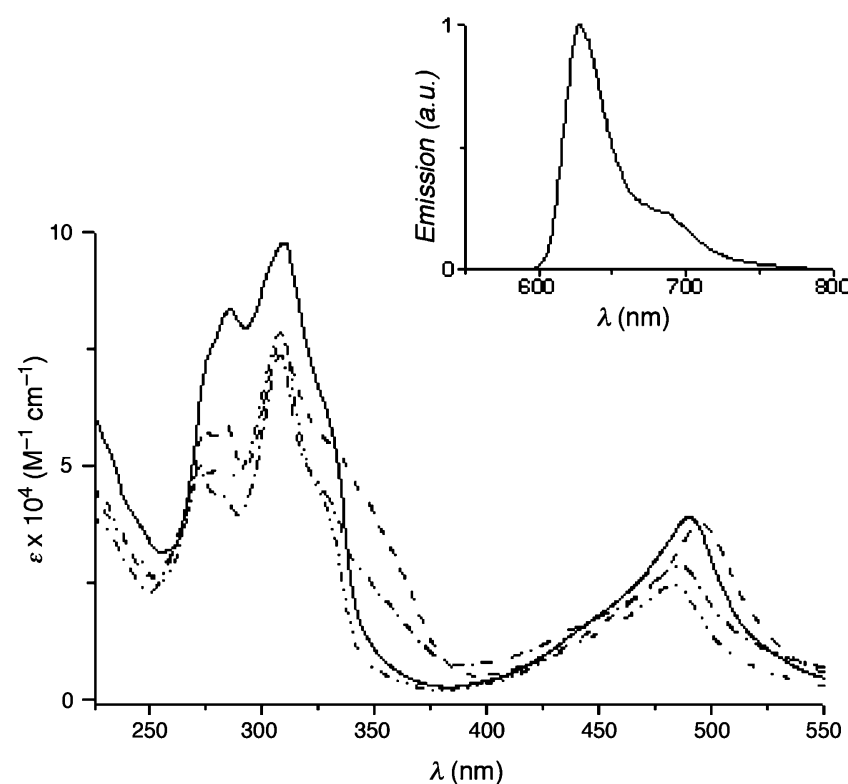

Figure 4. UV-vis absorption spectra of complexes $5(-\cdot-), 7$ $(-\cdot-), 6(-)$, and $8(---)$ in $\mathrm{MeCN}$ at $298 \mathrm{~K}$. The inset shows the emission spectrum of complex 8 in butyronitrile at $77 \mathrm{~K}\left(\lambda_{\mathrm{ex}}=480 \mathrm{~nm}\right)$.

Scheme 3. Synthesis of Heterodi- and Trimetallic Complexes 7 and $\mathbf{8}^{a}$<smiles></smiles>

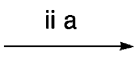

i

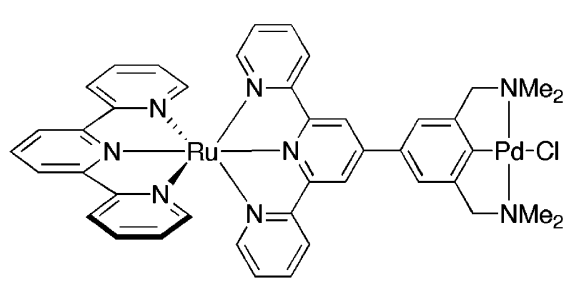

$\left(\mathrm{PF}_{6}\right)_{2}$

$7 \quad[\mathrm{Ru}(\mathrm{TPPdCl})(\mathrm{tpy})]\left(\mathrm{PF}_{6}\right)_{2}$

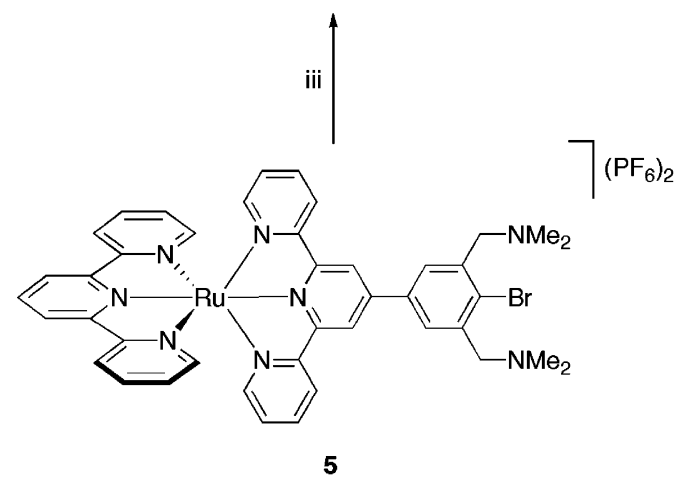

Table 3. Electronic Absorption and Emission Data

\begin{tabular}{|c|c|c|}
\hline compd & $\begin{array}{c}\lambda_{\max }(\mathrm{nm})^{a} \\
\left(\epsilon_{\max } \times 10^{4}\left(\mathrm{M}^{-1} \mathrm{~cm}^{-1}\right)\right)\end{array}$ & $\begin{array}{c}\lambda_{\mathrm{em}}(\mathrm{nm})^{b} \\
(\tau(\mu \mathrm{s}))\end{array}$ \\
\hline$[\mathrm{PdCl}(\mathrm{NCN})](\mathbf{9})$ & $\begin{array}{l}255(4.02), 279(1.95), 286(1.96), \\
\quad 307(1.30)\end{array}$ & $\mathrm{nd}^{c}$ \\
\hline$\left[\mathrm{Ru}(\mathrm{tpy})_{2}\right]^{2+d}$ & $307(5.2), 475(1.26)$ & $598(11)$ \\
\hline$[\mathrm{TPBr}](3)^{e}$ & $\begin{array}{l}255(3.46), 280(4.30), \\
320 \operatorname{sh}(0.63)\end{array}$ & nd \\
\hline$[\mathrm{PdC}$ & $293(3.70), 330 \mathrm{sh}(1.65)$ & nd \\
\hline$[\mathrm{Ru}(\mathrm{TPBr})(\mathrm{tpy})]^{2+}$ & $308(5.9), 483(1.80)$ & $624(14)$ \\
\hline$\left[\mathrm{Ru}(\mathbf{T P B r})_{2}\right]^{2+}(\mathbf{6})$ & $318(6.2), 490(2.50)$ & $629(13)$ \\
\hline$[\mathrm{Ru}(\mathrm{TPPdCl})(\text { tpy })]^{2}$ & $271(3.50), 308(5.0)$, & $624(15)$ \\
\hline$[\mathrm{Ru}(\mathrm{TPPdCl})]^{2+}(\mathbf{8})$ & $283(3.75), 308(4.9) 496(1.8)$ & $630(13)$ \\
\hline$[\operatorname{Ru}(\mathbf{T P P d S C N})(\mathrm{tpy})]^{2+}(\mathbf{1 0})$ & $\begin{array}{l}272(3.27), 309(3.43), \\
487(2.94)\end{array}$ & nd \\
\hline
\end{tabular}

${ }^{a}$ Measured at $298 \mathrm{~K}$ in $\mathrm{MeCN} .{ }^{b}$ Measured at $77 \mathrm{~K}$ in a butyronitrile glass $\left(\lambda_{\mathrm{ex}}=480 \mathrm{~nm}\right) .{ }^{c}$ n.d. $=$ not determined. ${ }^{d}$ See ref $3 \mathrm{~d} .{ }^{e}$ Measured at $298 \mathrm{~K}$ in $\mathrm{CH}_{2} \mathrm{Cl}_{2}$.

Electronic Absorption Spectra. Table 3 reports the absorption maxima $\left(\lambda_{\max }\right)$ and molar absorption extinction coefficients $\left(\epsilon_{\max }\right)$ for $\mathbf{3}$ and $\mathbf{4 b}$ in $\mathrm{CH}_{2} \mathrm{Cl}_{2}$ and for 5-8 in $\mathrm{MeCN}$ (elelctronic spectra in Figures 3 and 4, respectively). Data for the pincer complex $\left[\mathrm{PdCl}\left\{\mathrm{C}_{6} \mathrm{H}_{3}\left(\mathrm{CH}_{2} \mathrm{NMe}_{2}\right)_{2}-2,6\right\}\right]$ (9) ${ }^{17}$ and the reference compound $\left[\mathrm{Ru}(\mathrm{tpy})_{2}\right]\left(\mathrm{PF}_{6}\right)_{2}{ }^{3 \mathrm{~d}}$ have also been included for comparison.
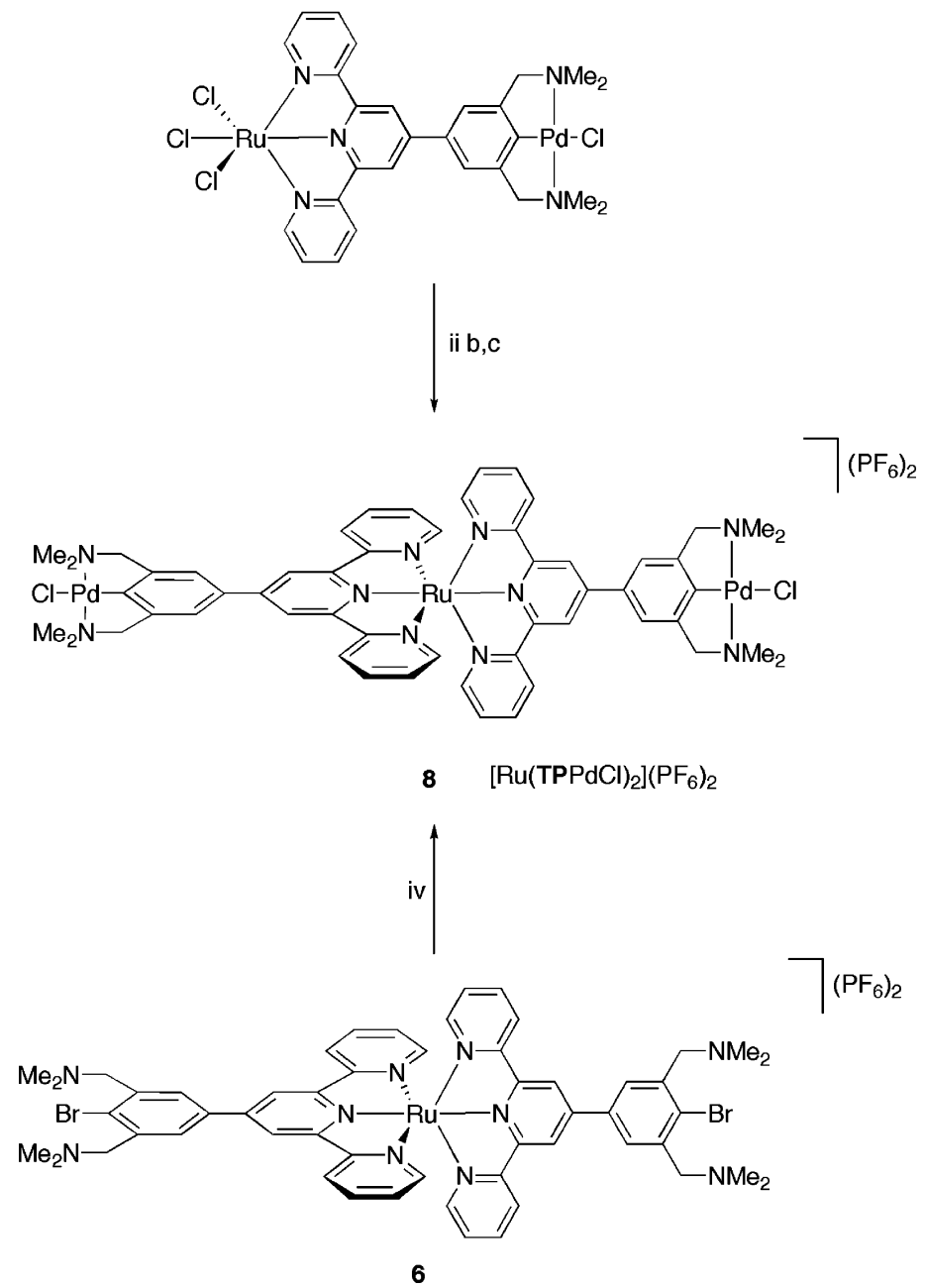

${ }^{a}$ Reagents and conditions: (i) (a) $\left[\mathrm{RuCl}_{3}\right.$ (tpy)], $\mathrm{N}$-ethylmorpholine, $\mathrm{MeOH}$, reflux, $1 \mathrm{~h}$; (b) $\mathrm{NaPF}_{6}, \mathrm{MeOH}$. (ii) (a) $\mathrm{RuCl}_{3} \cdot 3 \mathrm{H}_{2} \mathrm{O}$ ( 1 equiv), EtOH, reflux, $1 \mathrm{~h}$; (b) $4 \mathbf{b}$ (1 equiv) and $\mathrm{N}$-ethylmorpholine, $\mathrm{MeOH}$, reflux, $1.5 \mathrm{~h}$; (c) $\mathrm{NaPF}_{6}, \mathrm{MeOH}$. (iii) $\left[\mathrm{Pd}_{2}\left(\mathrm{dba}_{3}\right] \cdot \mathrm{CHCl}_{3}(0.5 \mathrm{equiv}), \mathrm{C}_{6} \mathrm{H}_{6}, \mathrm{reflux}, 2 \mathrm{~h}\right.$. (iv) (a) $\left[\mathrm{Pd}_{2}(\mathrm{dba})_{3}\right] \cdot \mathrm{CHCl}_{3}$ (2 equiv), reflux, $2 \mathrm{~h}$; (b) $\mathrm{Me}_{3} \mathrm{SiOTf}$ (2 equiv), $\mathrm{CH}_{2} \mathrm{Cl}_{2}$; (c) $\mathrm{NaCl}$, acetone. 


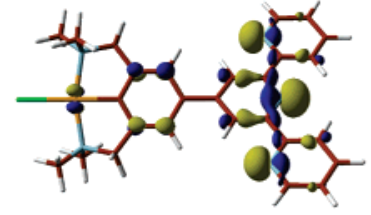

4b: HOMO-6; $-6.75 \mathrm{eV}$

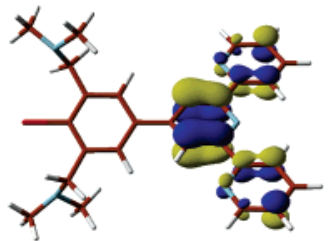

3: HOMO-3; $-6.44 \mathrm{eV}$

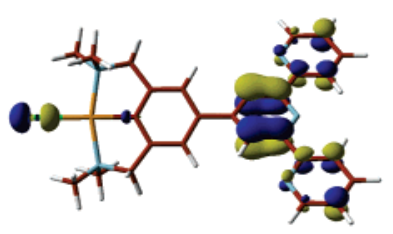

4b: HOMO-5; $-6.64 \mathrm{eV}$

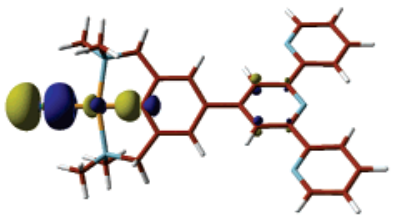

4b: HOMO-4; $-6.40 \mathrm{eV}$

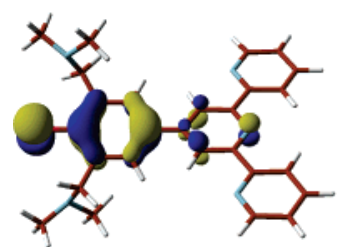

3: HOMO-2; $-6.22 \mathrm{eV}$

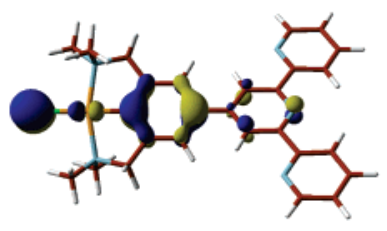

4b: HOMO-3; -6.27 eV

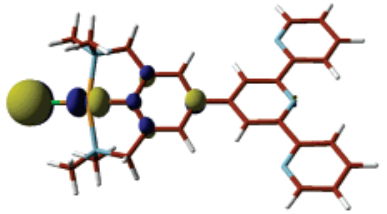

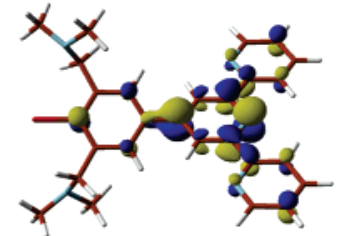

3: LUMO; $-1.79 \mathrm{eV}$

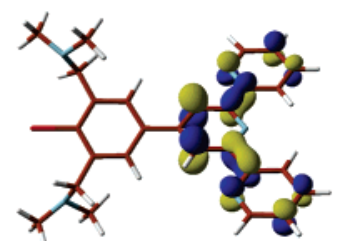

3: LUMO+1;-1.73 eV

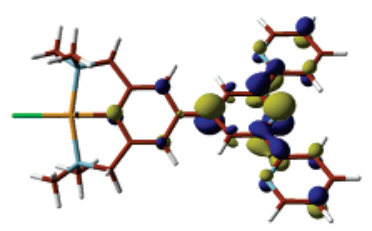

4b: LUMO; $-1.76 \mathrm{eV}$

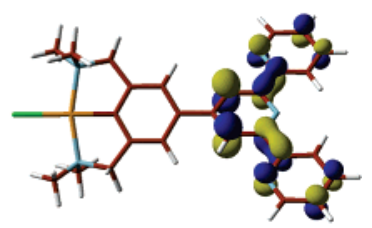

4b: LUMO+1; - $1.74 \mathrm{eV}$

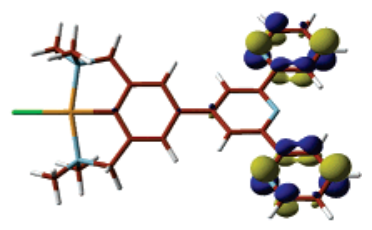

4b: LUMO+2; -1.00 eV

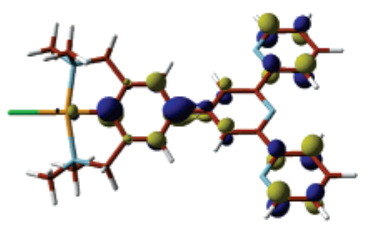

4b: LUMO+5; $-0.63 \mathrm{eV}$

4b: HOMO; $-5.48 \mathrm{eV}$

Figure 5. Contour plot of HOMOs and LUMOs of $\mathbf{3}$ and $\mathbf{4 b}$ calculated at the B3LYP/LANL2-DZ level, involved in the electronic transitions presented in Table 5.

The electronic spectrum of $\mathbf{3}$ (Figure 3 ) is not the simple sum of the spectra of the unsubstituted tpy $\left(\lambda_{\max }=280 \mathrm{~nm}\right.$; $\left.\log \epsilon_{\max }=4.3\right)$ and the pincer ligand $\left[\mathrm{BrC}_{6} \mathrm{H}_{3}\left(\mathrm{CH}_{2} \mathrm{NMe}_{2}\right)_{2}-\right.$ $2,6](\mathrm{NCNBr})\left(\lambda_{\max }=269 \mathrm{~nm} ; \log \epsilon_{\max }=1\right.$.) (Figure 3, inset). This suggests that the tpy and $\mathrm{NCNBr}$-pincer moieties in ligand $\mathbf{3}$ are not fully electronically independent but rather weakly coupled.

The electronic absorption spectrum of complex $\mathbf{4 b}$ shows in the UV region a band pattern similar to that of ligand $\mathbf{8}$ but slightly shifted to a lower energy. The main difference is an intense shoulder dominating the $300-350 \mathrm{~nm}$ region and tailing down to $450 \mathrm{~nm}$.

To understand the changes in the spectrum of the free ligand caused by coordination of the $\mathrm{Pd}-\mathrm{Cl}$ moiety and to elucidate the origin of the new low-lying transitions, we decided to calculate the electronic spectra of both compounds using the time-dependent DFT (TD-DFT) approach (at the B3LYP/LANL2-DZ level). Table 4 presents the low-lying
Table 4. TD-DFT Excitation Energies $(E)$ and Non-Vanishing Oscillator Strengths $(f>0.02)$ Calculated for $\mathbf{3}$ and $\mathbf{4 b}$

\begin{tabular}{|c|c|c|c|c|}
\hline state & composition & $E(\mathrm{eV})$ & $\begin{array}{c}\text { wavelength } \\
(\mathrm{nm})\end{array}$ & $f$ \\
\hline \multicolumn{5}{|c|}{3} \\
\hline $7 \mathrm{~A}$ & $62 \%(\mathrm{H}-2 \rightarrow \mathrm{L}+1) ; 34 \%(\mathrm{H}-3 \rightarrow \mathrm{L})$ & 3.89 & 319 & 0.030 \\
\hline $11 \mathrm{~A}$ & $92 \%(\mathrm{H}-2 \rightarrow \mathrm{L})$ & 4.07 & 305 & 0.367 \\
\hline $16 \mathrm{~A}$ & $56 \%(\mathrm{H}-3 \rightarrow \mathrm{L}) ; 36 \%(\mathrm{H}-2 \rightarrow \mathrm{L}+1)$ & 4.21 & 294 & 0.223 \\
\hline $21 \mathrm{~A}$ & $87 \%(\mathrm{H}-3 \rightarrow \mathrm{L}+1)$ & 4.39 & 283 & 0.272 \\
\hline $3 \mathrm{~A}$ & $95 \%(\mathrm{H} \rightarrow \mathrm{L})$ & 3.39 & 366 & 0.020 \\
\hline \multicolumn{5}{|c|}{$4 b$} \\
\hline $11 \mathrm{~A}$ & $\begin{array}{l}41 \%(\mathrm{H}-3 \rightarrow \mathrm{L}+1) ; 29 \% \\
\quad(\mathrm{H}-5 \rightarrow \mathrm{L}) ; 9 \%(\mathrm{H}-6 \rightarrow \mathrm{L})\end{array}$ & 4.00 & 310 & 0.051 \\
\hline $14 \mathrm{~A}$ & $73 \%(\mathrm{H}-3 \rightarrow \mathrm{L}) ; 16 \%(\mathrm{H} \rightarrow \mathrm{L}+2)$ & 4.13 & 300 & 0.105 \\
\hline $16 \mathrm{~A}$ & $81 \%(\mathrm{H} \rightarrow \mathrm{L}+2) ; 15 \%(\mathrm{H}-3 \rightarrow \mathrm{L})$ & 4.1 & 297 & 0.190 \\
\hline $17 \mathrm{~A}$ & $30 \%(\mathrm{H}-5 \rightarrow \mathrm{L}) ; 16 \%(\mathrm{H}-8 \rightarrow \mathrm{L}+1)$ & 4.2. & 292 & 0.182 \\
\hline $21 \mathrm{~A}$ & $\begin{array}{l}59 \%(\mathrm{H}-4 \rightarrow \mathrm{L}+1) ; 22 \% \\
\quad(\mathrm{H}-5 \rightarrow \mathrm{L}+1) ; 9 \%(\mathrm{H} \rightarrow \mathrm{L}+5)\end{array}$ & 4.35 & 285 & 0.320 \\
\hline
\end{tabular}

electronic transitions in $\mathbf{3}$ and $\mathbf{4 b}$ with oscillator strengths larger than 0.02 . The calculated TD-DFT values are in reasonable agreement with the experimental absorption maxima of both compounds. 
The occupied and virtual molecular orbitals involved in the electronic transitions of $\mathbf{3}$ and $\mathbf{4 b}$ are depicted in Figure 5 . The (HOMO -3 ) and (LUMO +1$)$ of $\mathbf{3}$ and the (HOMO -5 )and (LUMO +1 ) of $\mathbf{4 b}$ have the same $\pi$ character and are localized exclusively on the tpy subunit ( $\pi$ (tpy) and $\pi^{*}$ (tpy), respectively). The $\pi^{*}$ (tpy) character can also be attributed to the LUMO of these compounds, which is, however, partly localized on the ring $\pi$-system of the NCNpincer subunit. The (HOMO - 2) of 3 and the (HOMO 3 ) of $\mathbf{4 b}$ are mainly localized on the NCN-pincer ring and, to a minor extent, on the central pyridine ring of the tpy subunit. No equivalent high-lying occupied molecular orbitals of 3 are found for the HOMO and (HOMO - 4) of $\mathbf{4 b}$, as these orbitals show dominant contributions from the $\mathrm{Pd}-\mathrm{Cl}$ moiety, with a partial involvement of the NCN-pincer ring: $\pi^{*}(\mathrm{Pd}-\mathrm{Cl})$ and $\pi^{*}(\mathrm{Cl}-\mathrm{Pd}-\mathrm{C})$, respectively.

Taking into account the close correspondence between the orbitals, we conclude that the intraligand (IL) transitions to the 7A, 11A, and 16A states of $\mathbf{3}$ (Table 4) have natures similar to those of the $11 \mathrm{~A}, 14 \mathrm{~A}$, and 17A states of $\mathbf{4 b}$, respectively. However, we must not forget the major contribution of the $\mathrm{Pd}-\mathrm{Cl}$ moiety to the (HOMO -3$)$ of 4b, which also attributes to the $11 \mathrm{~A}$ and $14 \mathrm{~A}$ states a significant metal-to-ligand, MLCT, and ligand-to-ligand, LLCT, charge-transfer, character, respectively.

Upon coordination of the $\mathrm{Cl}-\mathrm{Pd}$ fragment to ligand 3, two new excitations appear in the near-UV region spectrum of $4 \mathrm{~b}$ : to the $3 \mathrm{~A}$ state (calculated at $365 \mathrm{~nm}, \mathrm{HOMO} \rightarrow$ LUMO) and to the 16A state (calculated at $297 \mathrm{~nm}, \mathrm{HOMO}$ $\rightarrow(\mathrm{LUMO}+2)$ and $(\mathrm{HOMO}-3) \rightarrow$ LUMO), both having a mixed LLCT/MLCT character with a dominant $\pi^{*}(\mathrm{Pd}-$ $\mathrm{Cl}) \rightarrow \pi^{*}$ (tpy) component. Comparison of the experimental electronic absorption spectra with the calculated transitions leads to the following assignments. The intense experimental band at $280 \mathrm{~nm}$ in the spectrum of $\mathbf{3}$ can be attributed to the close-lying transitions $11 \mathrm{~A}$ and $16 \mathrm{~A}$ calculated at 305 and $294 \mathrm{~nm}$, with large oscillator strengths and combined $\pi^{*}$ $(\mathrm{Br}-\mathrm{NCN}) \rightarrow \pi^{*}$ (tpy) and $\pi($ tpy $) \rightarrow \pi^{*}$ (tpy) character. The band at $255 \mathrm{~nm}$ probably arises because of the $\pi$ (tpy) $\rightarrow \pi^{*}$ (tpy) transition to the $21 \mathrm{~A}$ state, calculated at $283 \mathrm{~nm}$. The weak shoulder at $320 \mathrm{~nm}$ then corresponds to the much less intense transition 7A with a prevailing $\pi^{*}(\mathrm{Br}-\mathrm{NCN}) \rightarrow \pi^{*}$ (tpy) character.

The transitions calculated for $\mathbf{4 b}$ at 285, 292, 297, and $300 \mathrm{~nm}$ contribute to the overall shape of the intense experimental absorption band of the complex at $293 \mathrm{~nm}$. Considering the large contribution of the $\mathrm{d}_{\pi}(\mathrm{Pd})$ and $\mathrm{p}_{\pi}(\mathrm{Cl})$ orbitals to the HOMO and (HOMO - 3), it can be concluded that the intense band at $293 \mathrm{~nm}$ (encompassing the excitations to the 14A, 16A, and 17A states) has a mixed $\pi($ tpy $) \rightarrow \pi^{*}$ (tpy) (IL) and $\pi^{*}(\mathrm{Cl}-\mathrm{Pd}-\mathrm{NCN}) \rightarrow \pi^{*}$ (tpy) (LLCT/MLCT) character. The shoulder at $330 \mathrm{~nm}$ in the spectrum of $\mathbf{9 b}$ has more than double the intensity of ligand $\mathbf{3}$ at $320 \mathrm{~nm}$. This comparison facilitates its assignment to the electronic transition $11 \mathrm{~A}$ calculated at $309 \mathrm{~nm}$ and the signal has nearly double the oscillator strength of that of the 7A transition of ligand 3. This difference is probably caused by the coordination of the $\mathrm{Pd}-\mathrm{Cl}$ moiety, which again attributes the $11 \mathrm{~A}$ transition to a partial $\pi(\mathrm{Cl}-\mathrm{Pd}) / \pi(\mathrm{NCN}) \rightarrow \pi^{*}(\mathrm{tpy})\left(\mathrm{L}^{\prime} \mathrm{LCT} /\right.$ MLCT) character. This absorption feature is also apparent in the electronic absorption spectra of the heterometallic complexes 7 and $\mathbf{8}$ (see below). The new HOMO $\rightarrow$ LUMO transition of complex $\mathbf{4 b}(3 \mathrm{~A})$, with a mixed $\pi^{*}(\mathrm{Cl}-\mathrm{Pd}-$ $\mathrm{NCN}) \rightarrow \pi^{*}$ (tpy) (LLCT/MLCT) character and a low oscillator strength, was calculated at $366 \mathrm{~nm}$. It is probably partly hidden under the intense shoulder at $330 \mathrm{~nm}$ and corresponds to the tailing observable down to $420 \mathrm{~nm}$ (Figure 3).

The electronic absorption spectra of the Ru-containing complexes 5-8 (Figure 4) display features that can be interpreted by comparison with the literature data ${ }^{1}$ and on grounds of the TD-DFT analysis (vide supra). The intense absorption bands in the UV region between 250 and 320 $\mathrm{nm}$ (Table 3 ) belong to the spin-allowed $\pi \rightarrow \pi^{*}$ (tpy) and $\pi^{*} \rightarrow \pi^{*}$ (tpy) (IL/LLCT/MLCT) transitions that are derived from the $\mathrm{Pd}-\mathrm{Cl}, \mathrm{NCN}$-pincer, and tpy moieties, as discussed above for ligand 3 (7A, 11A, 16A, 21A) and complex $\mathbf{4 b}$ (11A, 14A, 16A, 17A). Electronic spectra of complexes 7 and $\mathbf{8}$ also display a shoulder at ca. $360 \mathrm{~nm}$, which is absent in the spectra of the mononuclear $\mathrm{Ru}$ complexes $\mathbf{5}$ and $\mathbf{6}$. For complex 8 with two $\mathrm{Pd}-\mathrm{Cl}$ moieties bound to the $\mathrm{NCN}$ pincer termini, the shoulder has nearly double the intensity of that in complex 7 with a single $\mathbf{T P P d}-\mathrm{Cl}$ chromophore. On the basis of these observations, we determine that the corresponding electronic transition probably has the same $\pi^{*}(\mathrm{Cl}-\mathrm{Pd}-\mathrm{NCN}) \rightarrow \pi^{*}$ (tpy) (LLCT/MLCT) origin as the HOMO $\rightarrow$ LUMO transition (3A) of complex $\mathbf{4 b}$, which is calculated and observed at the same energy (vide supra).

For all Ru-containing complexes 5-8, less-intense composed absorption bands fall in the visible spectral region $\left(\lambda_{\max }\right.$ $\left.=483-500 \mathrm{~nm} ; \log \epsilon_{\max }=4.3-4.4\right)$. They can be straightforwardly assigned to electronic transitions with a predominant $\mathrm{d}_{\pi}(\mathrm{Ru}) \rightarrow \pi^{*}$ (tpy) charge-transfer (MLCT) character $^{1}$ involving both the tpy moiety of ligand $\mathbf{3}$ and the peripheral tpy ligand. Comparison of the mononuclear $\mathrm{Ru}$ unsymmetric complexes 5 and $\mathbf{7}$ with the reference compound $\left[\mathrm{Ru}(\mathrm{tpy})_{2}\right]\left(\mathrm{PF}_{6}\right)_{2}{ }^{3 \mathrm{~d}}\left(\lambda_{\max }=475 \mathrm{~nm} ; \log \epsilon_{\max }=4.1\right)$ reveals that their MLCT maxima are slightly red-shifted (and gain extra intensity) with the increasing substitution at the $4^{\prime}$-position of the peripheral tpy ligands with the NCNBrpincer moiety. We have attributed the red shift (see also emission spectra) to the lowest excited state that is localized on the unsubstituted tpy because of the electron-donating character of the tpy moiety of ligand 3 . The bathochromic shift becomes slightly larger for the symmetric complexes 6 and $\mathbf{8}$, most likely because of an extension of the $\pi$-system and stabilization of the lowest MLCT state(s). Coordination of the $\mathrm{Pd}-\mathrm{Cl}$ fragments to the $\mathrm{NCN}$-pincer termini in the heterometallic complexes $\mathbf{7}$ and $\mathbf{8}$ does not result in significant changes in the spectra compared to the spectra of the palladium-free species, indicating a weak intercomponent coupling. ${ }^{\text {la }}$

Electrochemistry. Cyclic and square wave voltammetries in $\mathrm{MeCN}$ solutions were applied to study the redox properties of the $\mathrm{Pd}^{\mathrm{II}}$-based complexes $\mathbf{4} \mathbf{b}$ and $\left[\mathrm{PdCl}\left\{\mathrm{C}_{6} \mathrm{H}_{3}\left(\mathrm{CH}_{2} \mathrm{NMe}_{2}\right)_{2}-\right.\right.$ $2,6\}]\left([\mathrm{PdCl}(\mathrm{NCN})](\mathbf{9})\right.$ and the $\mathrm{Ru}^{\mathrm{II}}$-based complexes 5-8. 
Table 5. Electrochemical Data for Complexes $4 \mathbf{b}, \mathbf{5}-\mathbf{8}, \mathbf{1 0}$, and the Reference Compound ${ }^{a}$

\begin{tabular}{lcccc}
\hline \multicolumn{1}{c}{ compd } & $\begin{array}{c}E_{\mathrm{p}, \mathrm{a}}(\mathrm{ox}) \\
\text { Pd-based }\end{array}$ & $\begin{array}{c}E_{1 / 2}(\mathrm{ox}) \\
\text { Ru-based }\end{array}$ & $E_{1 / 2}(\mathrm{red})$ \\
\hline$[\mathrm{PdCl}(\mathrm{NCN})](\mathbf{9})$ & $0.69^{d}$ & & & \\
{$\left[\mathrm{Ru}(\mathrm{tpy})_{2}\right]^{2+c}$} & & 0.98 & -1.58 & -1.86 \\
{$[\mathrm{Ru}(\mathbf{T P B r})(\mathrm{tpy})]^{2+}(\mathbf{5})$} & & 0.82 & -1.62 & -1.89 \\
{$\left[\mathrm{Ru}(\mathbf{T P B r})_{2}\right]^{2+}(\mathbf{6})$} & & 0.87 & -1.63 & -1.90 \\
{$[\operatorname{Ru}(\mathbf{T P P d C l})(\mathrm{tpy})]^{2+}(\mathbf{7})$} & & 0.81 & -1.67 & -1.92 \\
{$\left[\operatorname{Ru}(\mathbf{T P P d C l})_{2}\right]^{2+}(\mathbf{8})$} & & 0.82 & -1.68 & -1.98 \\
{$[\operatorname{Ru}(\mathbf{T P P d S C N})(\mathrm{tpy})]^{2+}(\mathbf{1 0})^{d}$} & & 0.85 & -1.65 & -1.92
\end{tabular}

${ }^{a}$ Measured at $298 \mathrm{~K}$ in MeCN. $(0.1 \mathrm{M}$ TBAH; scan rate $=100 \mathrm{mV}$ $\mathrm{s}^{-1}$ ). Potentials reported in volts vs $\mathrm{Fc} / \mathrm{Fc}^{+}$. ${ }^{b}$ Measured at $298 \mathrm{~K}_{\text {in }} \mathrm{CH}_{2} \mathrm{Cl}_{2}$. ${ }^{c}$ See ref 3 d. ${ }^{d}$ Measured at $298 \mathrm{~K}$ in butyronitrile.

Table 5 presents redox potentials for all the studied complexes and the reference compound $\left[\mathrm{Ru}(\mathrm{tpy})_{2}\right]\left(\mathrm{PF}_{6}\right)_{2}{ }^{3 \mathrm{~d}}$

The cyclic voltammogram of $\mathbf{9}$ exhibits an irreversible oxidation at $0.69 \mathrm{~V}$, similar to that of related monoanionic NCN-pincer ligands reported elsewhere. ${ }^{19,20}$ This suggests that upon oxidation, reorganization takes place. Para functionalization of 9 with a tpy ligand (i.e., construction of $\mathbf{4 b}$ ) results in a considerable change of the redox properties of the palladium center. For $\mathbf{4 b}([\mathrm{PdCl}(\mathbf{T P})])$, no $\mathrm{Pd}^{\mathrm{II}}$-based oxidation process could be detected within the potential limits of the electrolyte. An inductive electronic effect of the tpy of the bridging ligand $\mathbf{3}$ might account for the shift of the formally $\mathrm{Pd}^{\mathrm{II}}$-based oxidation to potentials higher than those of 9 (Mulliken ${ }^{21}$ populations: tpy/[NCNPdCl] $=138.9 / 121.1$ electrons instead of the ideal of 139.0/121.0).

The anodic potential region of the voltammograms of the studied $\mathrm{Ru}^{\mathrm{II}}$-based complexes $\mathbf{5}-\mathbf{8}$ exhibits a reversible oneelectron wave for the $\mathrm{Ru}^{\mathrm{II}} / \mathrm{Ru}^{\mathrm{III}}$ redox couple, which is $100-$ $160 \mathrm{mV}$ less positive than the oxidation potential of $\left[\mathrm{Ru}\left(\mathrm{tpy}_{2}\right)_{2}\right]\left(\mathrm{PF}_{6}\right)_{2}{ }^{3 \mathrm{~d}}$ (see Table 3). Previously reported DFT calculations on $\left[\mathrm{Ru}(\text { tpy })_{2}\right]^{2+}$ and the analogous system $[\mathrm{Ru}-$ $\left.(t \text {-Bu-phtpy })_{2}\right]^{2+}$ are in line with the observed behavior. ${ }^{22}$ From the HOMO energies of $\left[\mathrm{Ru}(\mathrm{tpy})_{2}\right]^{2+}$ and $[\mathrm{Ru}(t-\mathrm{Bu}-$ phtpy $\left.)_{2}\right]^{2+}$, it follows that the latter complex is more prone to oxidation. ${ }^{22}$ The data reported in Table 3 reveal that the $\mathrm{Ru}^{\mathrm{II}} / \mathrm{Ru}^{\mathrm{III}}$ oxidation potentials of the monometallic species (5 and 6) fall in the same anodic region as those obtained for the heterodi- and trimetallic complexes (7 and $\mathbf{8}$ ). This result points to a limited electronic communication between the $\mathrm{Ru}^{\mathrm{II}}$ and $\mathrm{Pd}^{\mathrm{II}}$ centers in the ground state, weakly mediated by the bridging ligand $\mathbf{3}$. It is interesting to note that for complexes $\mathbf{7}$ and $\mathbf{8}$, no $\mathrm{Pd}^{\mathrm{II}}$-based oxidation process could be detected within the anodic potential limits of the electrolyte.

Two reversible one-electron cathodic waves belong to the reduction of the substituted and unsubstituted tpy moieties. ${ }^{1}$ For both heteroleptic (5 and 7) and homoleptic (6 and 8) complexes, the initial reduction is shifted to potentials that

(19) (a) Hershel, J.; Krause Bauer, J. A.; Connick, W. B. Inorg. Chem. 2004, 43, 725 .

(20) (a) Back, S.; Lutz, M.; Spek, A. L.; Lang, H.; van Koten, G. $J$. Organomet. Chem. 2001, 620, 227. (b) Back, S.; Gossage, R. A.; Lutz, M.; del Rio, I.; Spek, A. L.; Lang, H.; van Koten, G. Organometallics 2000, 19, 3296.

(21) Mulliken, R. S. J. Chem. Phys. 1955, 23, 1833.

(22) Zhou, X.; Ren, A.-M.; Feng, J.-K. J. Organomet. Chem. 2005, 690, 338. are slightly lower than that for the parent compound $[\mathrm{Ru}-$ (tpy) $)_{2}\left(\mathrm{PF}_{6}\right)_{2}$ (Table 5). In particular, the presence of the $\mathrm{Pd}^{\mathrm{II}}$ ion contributes clearly to a slight decrease in the reduction potentials by $\sim 100 \mathrm{mV}$ in the heterodi- and trimetallic complexes $\mathbf{7}$ and $\mathbf{8}$. Thus, the functionalization of the $\mathrm{NCN}-$ pincer moiety with the $\mathrm{Pd}-\mathrm{Cl}$ fragment renders the bridging ligand more difficult to reduce.

In the cathodic potential region of all the complexes, additional irreversible processes occur at -2.29 and -2.38 $\mathrm{V}$ vs $\mathrm{Fc} / \mathrm{Fc}^{+}$that possibly involve the reduction of the pincer moiety. This hypothesis is supported by the results reported by Connick and co-workers, ${ }^{23}$ according to which no organometallic complexes containing NCN-pincer ligands undergo reduction at potentials less negative then $-1.8 \mathrm{~V}$.

IR and UV-Vis Spectroelectrochemistry. To collect more evidence for a weak electronic communication between the metal centers in the heterodinuclear species through the bridging ligand $\mathbf{3}$, we performed a cyclic voltammetric and IR/UV-vis spectroelectrochemical study of complex $\mathbf{1 0}$ $\left(\left[\mathrm{Ru}(\mathrm{TPPdSCN})(\right.\right.$ tpy) $\left.]\left(\mathrm{PF}_{6}\right)_{2}\right)$. Complex 10 contains $\mathrm{SCN}^{-}$ as a spectator ligand, i.e., a ligand that can easily be probed and does not affect the overall properties of the complex. The infrared spectrum of solid $\mathbf{1 0}$ displays a sharp $v(\mathrm{SCN})$ absorption band at $2080 \mathrm{~cm}^{-1}$, characteristic of an S-bonded thiocyanate group. ${ }^{24} \mathrm{On}$ the basis of the infrared spectrum, it can be concluded that the S-bonded species is the only product obtained by exchanging the chloride in 7 for $\mathrm{SCN}^{-}$ in reaction with $\mathrm{AgSCN}$. The exclusive S-bonding of the $\mathrm{SCN}^{-}$ligand is expected on the basis of the poor $\pi$-acceptor properties of the monoanionic NCN-pincer ligand, which enhances the relative tendency of the "soft" donor sulfur atom to participate in $\pi$-bonding.

The cyclic voltammogram of $\mathbf{1 0}$, recorded in butyronitrile at room temperature, exhibits features similar to those observed for the related system 7: a reversible $\mathrm{Ru}^{\mathrm{II}} / \mathrm{Ru}^{\mathrm{III}}$ anodic wave and two reversible one-electron tpy-centered cathodic processes (Table 5). Importantly, replacement of the $\mathrm{Cl}^{-}$ligand by the $\pi$-acceptor $\mathrm{SCN}^{-}$ligand clearly renders the $\mathrm{Pd}^{\mathrm{II}}$ center less electron-rich. This leads to a weaker back $\pi$-bonding interaction with the bridging ligand in $\mathbf{1 0}$ than in 7, which results in less-negative centered ligand reductions and a higher redox potential for the $\mathrm{Ru}^{\mathrm{II}} / \mathrm{Ru}^{\mathrm{III}}$ couple (Table 3).

The IR absorption spectrum of $\mathbf{1 0}$ in butyronitrile containing $0.1 \mathrm{M}$ TBAH displays again the sharp $v(\mathrm{SCN})$ band of the thiocyanato ligand at $2080 \mathrm{~cm}^{-1}$. This stretching mode forms a convenient probe for spectroelectrochemical monitoring of subtle changes in electron density at the palladium center caused by the tpy reduction.

One-electron reduction of $\mathbf{1 0}$ within an optically transparent thin-layer electrochemical (OTTLE) cell ${ }^{25}$ in butyronitrile

(23) Jude, H.; Krause Bauer, J. A.; Connick, W. B. J. Am. Chem. Soc. 2003, $125,3446$.

(24) Nakamoto, K. In Infrared and Raman Spectra of Inorganic and Coordination Compounds, 4th ed.; Wiley-Interscience: New York, 1997; p 117, part B

(25) (a) Krejcík, M.; Danek, M.; Hartl, F. J. Electroanal. Chem., Interfacial Electrochem. 1991, 317, 179. (b) Hartl, F.; Luyten, H.; Nieuwenhuis, H. A.; Schoemaker, G. C. Appl. Spectrosc. 1994, 48, 1522. 


\section{Gagliardo et al.}

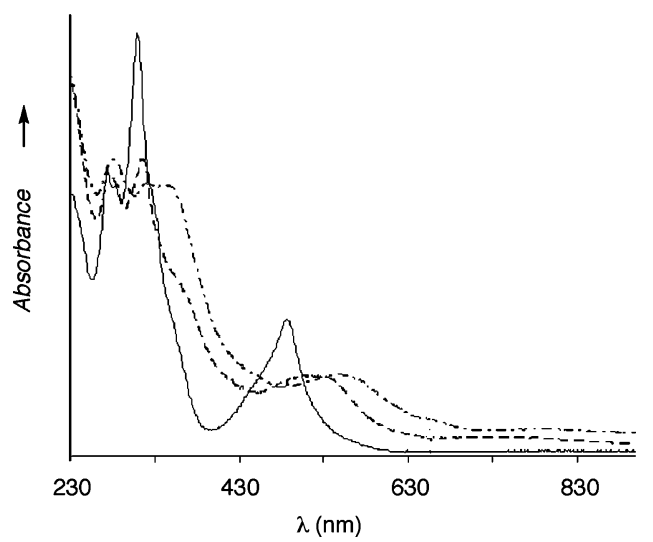

Figure 6. UV-vis spectra of $[\operatorname{Ru}(\operatorname{TPPdSCN})(\operatorname{tpy})]^{2+}(\mathbf{1 0})(-),[\mathrm{Ru}-$ (TPPdSCN)(tpy) $]^{+}\left(\mathbf{1 0}^{-}\right)(---)$, and $[\operatorname{Ru}(\mathrm{TPPdSCN})($ tpy $)]\left(\mathbf{1 0}^{2-}\right)$ $(-\cdot-)$, recorded in an OTTLE cell at $293 \mathrm{~K}$. The solvent was butyronitrile containing $0.1 \mathrm{M} \mathrm{TBAH}$.

at $293 \mathrm{~K}$ smoothly produced the stable cation [Ru(TPPd$\mathrm{SCN})(\mathrm{tpy})]^{+}\left(\mathbf{1 0}^{-}\right)$, as was documented by the thin-layer cyclic voltammogram recorded in the course of the experiment. The shape, position, and intensity of the $v(\mathrm{SCN})$ band remained unchanged. This observation is consistent with the first reduction step being localized at the peripheral (unsubstituted) tpy ligand. The addition of a second electron resulted in a shift of the $v(\mathrm{SCN})$ band from 2080 to $2050 \mathrm{~cm}^{-1}$. This shift to smaller wavenumbers could reflect an increased electron density at the $\mathrm{Pd}^{\mathrm{II}}$ center and increased $\pi$-backdonation to the thiocyanate ligand. However, reoxidation of the two-electron-reduced species $\mathbf{1 0}^{-2}$ did not completely recover the $2080 \mathrm{~cm}^{-1}$ band of $\mathbf{1 0}^{-}$, indicating that $\mathbf{1 0}^{-2}$ underwent a secondary chemical reaction on the time scale of the electrolysis, most likely involving only the TPPd$\mathrm{SCN}$ fragment. The reduced $\mathrm{Ru}-$ tpy moiety remained unaffected, as evidenced by the complete reversibility of the thin-layer voltammetric response. The inherent stability of the $\left\{\mathrm{Ru}(\mathrm{tpy})_{2}\right\}^{2+}$ core in the reduced complexes $\mathbf{1 0}^{-}$and $\mathbf{1 0}^{-2}$ was further confirmed by a parallel UV-vis spectroelectrochemical experiment using the OTTLE cell and a lessconcentrated solution. The UV-vis absorption spectra of $\mathbf{1 0}$ and its one- and two-electron reduced species, $\mathbf{1 0}^{-}$and $\mathbf{1 0}^{-2}$, are depicted in Figure 6. The spectrum of $\mathbf{1 0}$ displays characteristic features also observed for $\mathbf{7}$ (vide supra) and the reference compound $\left[\mathrm{Ru}(\mathrm{tpy})_{2}\right]\left(\mathrm{PF}_{6}\right)_{2}{ }^{3 \mathrm{~d}}$ : intense IL/ LLCT/MLCT ligand-centered transitions in the UV region $\left(\lambda_{\max }=272-310 \mathrm{~nm}\right.$ with $\left.\log \epsilon_{\max }=3.27-3.43\right)$ and $\mathrm{a} \mathrm{d}_{\pi^{-}}$ $(\mathrm{Ru}) \rightarrow \pi^{*}$ (tpy) metal-to-ligand-charge-transfer (MLCT) band at $\lambda_{\max }=487 \mathrm{~nm}\left(\log \epsilon_{\max }=2.94\right)$ (Table 4). ${ }^{3 \mathrm{~d}}$ Oneand two-electron reduction of $\mathbf{1 0}$ caused a red shift of the MLCT band at $487 \mathrm{~nm}$ to 524 and $554 \mathrm{~nm}$, respectively (Figure 6). Importantly, similar spectral changes were observed in the visible spectral region of the stepwise electrochemical reduction of the reference compound $[\mathrm{Ru}-$ (tpy) $\left.)_{2}\right]^{2+} .{ }^{26}$ At higher energy, the intense bands between 272 and $310 \mathrm{~nm}$, attributed to IL/LLCT/MLCT transitions, which involve the tpy moieties of the bridging ligand (vide infra), decrease considerably in intensity. Reoxidation of the one-

(26) Berger, R. M.; McMillin, D. R. Inorg. Chem. 1988, 27, 4245. electron reduced species $\mathbf{1 0}^{-}$completely regenerated the spectrum of $\mathbf{1 0}$, whereas the reoxidation of $\mathbf{1 0}^{2-}$ did not fully recover the UV-vis spectrum of $\mathbf{1 0}^{-}$and $\mathbf{1 0}$. In particular, the absorption bands in the UV region of the spectrum were lower in intensity. This behavior agrees with the conclusions from the IR spectroelectrochemical studies: two-electron reduced species $\mathbf{1 0}^{2-}$ undergoes some transformation of the $\mathrm{NCN}-\mathrm{Pd}$ fragment while the redox-active $\left\{\mathrm{Ru}(\mathrm{tpy})_{2}\right\}^{n}(n$ $=2+, 1+, 0)$ core remains intact. The reactivity of the $\mathrm{NCN}-\mathrm{Pd}-\mathrm{SCN}$ fragment documents the weak, but not negligible, tpy- $\mathrm{NCN}(\mathrm{Pd}-\mathrm{X})$ communication, as the second cathodic process is most likely localized on the tpy-NCN moiety.

Luminescence Properties. The luminescence of the $\mathrm{Ru}^{\mathrm{II}}$ based complexes $(\mathbf{5}-\mathbf{8})$ was investigated upon excitation with $480 \mathrm{~nm}$ light in deaerated acetonitrile at room temperature and in a frozen butyronitrile matrix at $77 \mathrm{~K}$. The luminescence band maxima and lifetimes are listed in Table 3. At room temperature, all complexes show a weak emission profile centered at $640 \mathrm{~nm}$, with lifetimes around $0.9 \mathrm{~ns}$. These values are very similar to those reported for reference compound $\left[\mathrm{Ru}\left(\mathrm{tpy}_{2}\right)_{2}\right]\left(\mathrm{PF}_{6}\right)_{2}\left(\lambda_{\max }=640 \mathrm{~nm} ; \tau=0.2 \mathrm{~ns}\right){ }^{3 \mathrm{~d}}$

It is recognized that for $\left[\mathrm{Ru}(\mathrm{tpy})_{2}\right]^{2+}$ and its derivatives, the room-temperature luminescence from the lowest ${ }^{3} \mathrm{MLCT}$ $(\mathrm{Ru} \rightarrow$ tpy) excited state is thermally quenched because of the population of low-lying ${ }^{3} \mathrm{MC}$ states that decay nonradiatively. ${ }^{1 \mathrm{a}, 5}$ However, in a glass matrix at $77 \mathrm{~K}$, the luminescence quantum yield can be high because of the lack of thermal activation. ${ }^{\text {la }}$

Although no detailed analysis has been carried out, we expect the same kind of photophysical properties for the complexes 5-8. In the butyronitrile matrixes at $77 \mathrm{~K}$, all the complexes indeed show bright red ${ }^{3}$ MLCT emission. The emission spectra (see inset of Figure 4) resemble that of [Ru$\left.(\text { tpy })_{2}\right]^{2+}$, although the maxima are red-shifted by about 30 $\mathrm{nm}$ because of the electron-donating substituents at the $4^{\prime}$ position of the tpy ligand (Table 3 ). ${ }^{1 \mathrm{~b}}$

Homoleptic complexes $\mathbf{6}$ and $\mathbf{8}$ emit at a slightly lower energy $\left(\lambda_{\max }=630 \mathrm{~nm}\right)$ than the heteroleptic species $\mathbf{5}$ and $7\left(\lambda_{\max }=624 \mathrm{~nm}\right)$ (Table 3). This minor shift may reflect, as already discussed for the absorption, the different terpyridine units involved in the lowest excited state. The emission lifetimes, determined with a streak camera interfaced to a nanosecond laser source set at $480 \mathrm{~nm}$, show similar differences as the emission maxima. The homoleptic complexes $\mathbf{6}$ and $\mathbf{8}$ exhibit identical emission lifetimes of $13 \mu \mathrm{s}$, whereas the heteroleptic complexes $\mathbf{5}$ and $\mathbf{7}$ live slightly longer: $14 \mu \mathrm{s}$ and $15 \mu \mathrm{s}$, respectively. The emission lifetimes of complexes 5-8 are anyway longer than that of the reference compound $\left[\mathrm{Ru}(\mathrm{tpy})_{2}\right]^{2+}(10.6 \mu \mathrm{s}),{ }^{1 \mathrm{a}}$ consistent with the previous reports on $\mathrm{Ru}^{\mathrm{II}}$-complexes with terpyridine ligands bearing electron-donating groups at the $4^{\prime}$-position. ${ }^{1 \mathrm{~b}}$ The small differences can be attributed to a higher degree of vibronic coupling to the ground state for those complexes emitting at a lower energy (6 and 8), with consequent shortening of the excited-state lifetime. The presence or absence of the $\mathrm{Pd}-\mathrm{Cl}$ moiety does not have a significant influence on the emission properties of the ruthenium-tpy 
chromophores. Thus, the ${ }^{3}$ MLCT excited state is approximately the same for all the complexes, confirming that the energies of the unsubstituted and substituted tpy are very similar. Furthermore, coordination of the palladium to the $\mathrm{NCNBr}$-pincer moieties has no detectable effect on the electronic properties of the chromophoric units, as already concluded from the electrochemical and electronic absorption data.

\section{Conclusions}

A novel heteroditopic ligand $\mathrm{TPBr}$ was synthesized in which properties of $2,2^{\prime}: 6^{\prime}, 2^{\prime \prime}$-terpyridine and $\mathrm{NCNBr}$-pincer $\left(\left[\mathrm{BrC}_{6} \mathrm{H}_{3}\left(\mathrm{CH}_{2} \mathrm{NMe}_{2}\right)_{2}-2,6\right]\right)$ ligands are combined. Like other bridging heteroditopic ligands based on terpyridine substituted at the 4'-position, TPBr can be regarded as an appealing rigid and linear bridging building block for the construction of one-dimensional nanostructures based on metal complexes. Selective metalation or coordination of the $\mathrm{NCNBr}$-pincer or tpy moieties with an appropriate transition-metal precursor affords mononuclear species that can be further used for the stepwise syntheses of nanometer-scale rigid rodlike heterodiand trimetallic species with a length up to 21.735(2) $\mathrm{A}$.

For all relevant complexes, oxidation of the ruthenium centers occurs at nearly identical anodic potentials. This observation indicates that in the ground state, the HOMOs are almost unaffected by the presence of covalently attached (non)metalated NCN-pincer units at the $4^{\prime}$-position of the tpy ligand. Nevertheless, minor differences in reduction potentials and the results of spectroscopic and spectroelectrochemical studies are consistent with a weak electronic interaction between the tpy and NCN-pincer subunits. It is important to point out that the large twist (dihedral) angle between these subunits, as observed for complexes $\mathbf{4 b}(23.7$ $\left.(3)^{\circ}\right)$ and $6\left(-39.6(12)\right.$ and $\left.-30.5(11)^{\circ}\right)$ with X-ray structural analysis, probably makes them almost electronically independent (geometric decoupling). ${ }^{1 b, k, 27}$ Combined with the high intensity of the MLCT transitions in the visible region $\left(\epsilon \approx 2 \times 10^{4} \mathrm{M}^{-1} \mathrm{~cm}^{-1}\right)$ and the possibility to bind a wide range of transition metals at the NCN-pincer moieties, the design features of the presented building blocks open the possibility of exploring syntheses of organometallic polymers with interesting redox and photophysical properties.

\section{Experimental Section}

General. All the experiments were carried out under a dry nitrogen atmosphere, using standard Schlenk techniques. Benzene, toluene, pentane, hexane, and diethyl ether $\left(\mathrm{Et}_{2} \mathrm{O}\right)$ were distilled from sodium/benzophenone. Dichloromethane was dried over $\mathrm{CaH}_{2}$. Methanol was dried over magnesium and used freshly distilled. The complexes $\left[\mathrm{Pd}_{2}(\mathrm{dba})_{3}\right] \cdot \mathrm{CHCl}_{3},{ }^{17}\left[\mathrm{Ru}(\mathrm{tpy}) \mathrm{Cl}_{3}\right]$, and ${ }^{18 \mathrm{~b}} 4^{\prime}$-triflato$2,2^{\prime}: 6^{\prime}, 2^{\prime \prime}$-terpyridine ${ }^{16}$ and compounds $\mathbf{1}^{11 \mathrm{a}}$ and $\mathbf{9}^{17}$ were synthesized according to literature procedures. All other reagents were used as purchased. ${ }^{1} \mathrm{H}(200.1$ or $300.1 \mathrm{MHz}),{ }^{13} \mathrm{C}(75 \mathrm{MHz})$, and ${ }^{31} \mathrm{P}(81$ $\mathrm{MHz}$ ) NMR spectra were recorded at $298 \mathrm{~K}$ on a Varian AC200 or Varian INOVA 300 spectrometers. Chemical shifts are given in ppm relative to the residual solvent signal $\left({ }^{1} \mathrm{H}\right.$ and ${ }^{13} \mathrm{C}$ NMR spectra)

(27) Lainé, P.; Bedioui, F.; Ochsenbein, P.; Marvaud, V.; Bonin, M.; Amouyal, E. J. Am. Chem. Soc. 2002, 124, 1364. or $85 \% \mathrm{H}_{3} \mathrm{PO}_{4}$ as an external reference ( ${ }^{31} \mathrm{P}$ NMR spectra). Elemental analyses were performed by Dornis und Kolbe, Mikroanalytisches Laboratorium, Müllheim ad Ruhr, Germany. Highresolution electron spray ionization (ESI) mass spectra were recorded with a Micromass LC-TOF mass spectrometer at the Department of Biomolecular Mass Spectrometry, Utrecht University.

Electronic Spectroscopic Measurements. UV-vis absorption spectra were obtained with a Varian Cary 1 spectrophotometer. Steady-state luminescence was measured in freshly distilled butyronitrile at $77 \mathrm{~K}$, using a Spex Fluorolog 1681 spectrofluorimeter equipped with a Xe arc light source, a Hamamatsu R928 photomultiplier tube detector, and double excitation and emission monochromators. Emission spectra were corrected for source intensity and detector response using standard correction curves. Deaerated solutions were prepared by the freeze-pump-thaw technique on a high-vacuum line. For nanosecond time-resolved emission measurements, a continuously tuned Coherent Infinity XPO laser (set at $480 \mathrm{~nm}$ ) working at $10 \mathrm{~Hz}$, with a pulse of $2 \mathrm{~ns}$ fwhm, was used as an excitation source. Full spectra and decays were recorded using a Hamamatsu C5680-21 streak camera equipped with an M 5677 sweep unit. The time resolution of this setup is about $200 \mathrm{ps}$, as limited by laser width. Estimated errors are as follows: band maxima, $\pm 2 \mathrm{~nm}$; relative luminescence intensity, $\pm 20 \%$; lifetimes, $\pm 10 \%$.

Electrochemical Experiments. Cyclic and square-wave voltammetric scans were performed with a gastight single-compartment cell under an atmosphere of dry nitrogen. The cell was equipped with a Pt microdisk working (apparent surface area of $0.42 \mathrm{~mm}^{2}$ ), Pt wire auxiliary, and Ag wire pseudoreference electrodes. The working electrode was carefully polished with a $0.25 \mu \mathrm{m}$ grain diamond paste between scans. The potential control was achieved with a PAR Model 283 potentiostat. All redox potentials are reported against the ferrocene-ferrocenium $\left(\mathrm{Fc} / \mathrm{Fc}^{+}\right)$redox couple used as an internal standard $\left(E_{1 / 2}=+0.63 \mathrm{~V}_{\text {vs NHE }}{ }^{28}\right) ;{ }^{29} 10^{-1} \mathrm{M}$ $\mathrm{Bu}_{4} \mathrm{NPF}_{6}$ was used as a supporting electrolyte. All electrochemical samples were $5 \times 10^{-4} \mathrm{M}$ in the studied complexes.

IR Spectroelectrochemistry. Experiments were performed with an optically transparent thin-layer electrochemical (OTTLE) cell ${ }^{25}$ equipped with a $\mathrm{Pt}$ minigrid working electrode and $\mathrm{CaF}_{2}$ optical windows. The controlled-potential electrolyses were carried out with a PA4 potentiostat (EKOM, Czech Republic). All the electrochemical samples were $5 \times 10^{-2}$ in the studied complex and contained $3 \times 10^{-1} \mathrm{M} \mathrm{Bu}_{4} \mathrm{NPF}_{6}$. IR spectra were recorded with a Bio-Rad FTS-7 spectrometer at $2 \mathrm{~cm}^{-1}$ resolution (16 scans).

Computational Details. Geometries of 3 and $\mathbf{4 b}\left(C_{1}\right.$ symmetry) were optimized at the B3LYP level using GAMESS-UK. ${ }^{30}$ TDDFT calculations were performed using the B3LYP exchange/ correlation functional with DALTON. ${ }^{31}$ The LANL2-DZ ${ }^{32}$ basis set was used Pd calculations, and the SV Dunning ${ }^{33}$ basis set as built in GAMESS-UK was used for all other atoms.

(28) Gritzner, G.; Kuta, J. Pure Appl. Chem. 1984, 56, 461.

(29) Pavlishchuk, V. V.; Addison, A. W. Inorg. Chim. Acta 2002, 298, 97.

(30) Guest, M. F.; Bush, L. J.; van Dam, H. J.; Sherwood, P.; Thomas, J. M. H.; van Lenthe, J. H.; Havenith, R. W. A.; Kendrick, J. J. Mol. Phys. 2005, 103, 719.

(31) DALTON, a molecular electronic structure program, Release 2.0; 2005, see http://www.kjemi.uio.no/software/dalton/dalton.html.

(32) a) Dunning, T. H., Jr.; Hay, P. J. In Modern Theoretical Chemistry; Schaefer, H. F., III, Ed.; Plenum Press: New York, 1977; Vol. 3. b) Hay, P. J.; Wadt, W. R. J. Chem. Phys. 1985, 82, 299.

(33) Dunning, T. H., Jr.; Hay, P. J. In Methods of Electronic Structure Theory; Schaefer, H. F., III, Ed.; Plenum Press: New York, 1977; Vol. 2. 
Table 6. Crystallographic Details

\begin{tabular}{|c|c|c|}
\hline & $4 a$ & 6 \\
\hline formula & $\mathrm{C}_{27} \mathrm{H}_{28} \mathrm{BrN}_{5} \mathrm{Pd}$ & $\begin{array}{l}{\left[\mathrm{C}_{54} \mathrm{H}_{56} \mathrm{Br}_{2} \mathrm{~N}_{10} \mathrm{Ru}\right]\left(\mathrm{PF}_{6}\right)_{2}} \\
0.4 \mathrm{C}_{2} \mathrm{H}_{3} \mathrm{~N}\end{array}$ \\
\hline $\mathrm{fw}$ & 608.85 & 1412.34 \\
\hline cryst color & yellow & red \\
\hline cryst size $\left(\mathrm{mm}^{3}\right)$ & $0.48 \times 0.30 \times 0.06$ & $0.30 \times 0.18 \times 0.06$ \\
\hline cryst syst & monoclinic & triclinic \\
\hline space group & $P 2_{1} / c$ (No. 14) & $P \overline{1}$ (No. 2) \\
\hline$a(\AA)$ & $14.6370(1)$ & $11.1057(2)$ \\
\hline $\mathrm{b}(\AA)$ & $9.1587(1)$ & $14.4557(2)$ \\
\hline$c(\AA)$ & $19.1888(2)$ & $20.2558(4)$ \\
\hline$\alpha(\operatorname{deg})$ & 90 & $88.9444(6)$ \\
\hline$\beta(\operatorname{deg})$ & $108.0173(3)$ & $84.7470(5)$ \\
\hline$\gamma(\mathrm{deg})$ & 90 & $68.7656(6)$ \\
\hline$V\left(\AA^{3}\right)$ & $2446.23(4)$ & $3017.99(9)$ \\
\hline$Z$ & 4 & 2 \\
\hline$D_{x}\left(\mathrm{~g} / \mathrm{cm}^{3}\right)$ & 1.653 & 1.554 \\
\hline$\mu\left(\mathrm{mm}^{-1}\right)$ & 2.418 & 1.720 \\
\hline$(\sin \theta / \lambda)_{\max }\left(\AA^{-1}\right)$ & 0.65 & 0.53 \\
\hline no. of maesured reflns & 47360 & 30377 \\
\hline abs corr & PLATON (DELABS) & PLATON (ABST) \\
\hline abs corr range & $0.46-0.83$ & $0.61-0.91$ \\
\hline no. of unique reflns & 5619 & 7622 \\
\hline params/restraints & $311 / 0$ & $895 / 1679$ \\
\hline $\mathrm{R} 1 / \mathrm{wR} 2[I>2 \sigma(I)]$ & $0.0270 / 0.0704$ & $0.0626 / 0.1736$ \\
\hline R1/wR2 (all reflns) & $0.0334 / 0.0731$ & $0.0770 / 0.1847$ \\
\hline$S$ & 1.059 & 1.052 \\
\hline$\rho_{\min / \max }\left(\mathrm{e} / \AA^{3}\right)$ & $-0.84 / 0.44$ & $-1.30 / 1.25$ \\
\hline
\end{tabular}

X-ray Structure Determinations. X-ray intensities were measured on a Nonius KappaCCD diffractometer with rotating anode and graphite monochromator $(\lambda=0.71073 \AA)$ at a temperature of $150(2) \mathrm{K}$. The structures were solved with automated Patterson methods ${ }^{34}$ and refined with SHELXL- $97^{35}$ on $F^{2}$ of all reflections. Non-hydrogen atoms were refined freely with anisotropic displacement parameters. In $\mathbf{4 a}$, all hydrogen atoms were located in the difference Fourier map; in 6, hydrogen atoms were introduced in geometrically idealized positions. In both structures, $\mathrm{H}$ atoms were refined with a riding model. In $\mathbf{6}$, the $\mathrm{PF}_{6}$ anions and one of the pincer arms were heavily disordered and the acetonitrile solvent molecule was refined with only partial occupation. Geometry calculations, drawings, and checks for higher symmetry were performed with the PLATON package. ${ }^{36}$ Further crystallographic details are given in Table 6.

Synthesis of Ligands and Complexes. $4^{\prime}-\left\{\mathrm{BrC}_{6} \mathrm{H}_{2}\left(\mathrm{CH}_{2} \mathrm{NMe}_{2}\right)_{2}-\right.$ 2,6\}-trimethyltin [ $\left.\mathrm{Me}_{3} \mathrm{SnNCNBr}\right]$ (2). A solution of $t \mathrm{BuLi}(6.38$ $\mathrm{mL}, 1.5 \mathrm{M}$ in pentane) was added dropwise to a solution of $\mathbf{1}(2.00$ $\mathrm{g}, 5.04 \mathrm{mmol})$ in $\mathrm{Et}_{2} \mathrm{O}(50 \mathrm{~mL})$ at $-100{ }^{\circ} \mathrm{C}$ under vigorous stirring. After $15 \mathrm{~min}$, a solution of $\mathrm{Me}_{3} \mathrm{SnCl}(1.5 \mathrm{~g}, 7.56 \mathrm{mmol})$ in $25 \mathrm{~mL}$ of $\mathrm{Et}_{2} \mathrm{O}$ was added. The resulting suspension was allowed to warm to room temperature and stirred overnight. Subsequently, water was added, and the obtained mixture was treated with $10^{-1} \mathrm{M} \mathrm{NaOH}$ $(0.5 \mathrm{~mL})$. The $\mathrm{Et}_{2} \mathrm{O}$ layer was separated, and the water layer was washed twice with $50 \mathrm{~mL}$ of $\mathrm{Et}_{2} \mathrm{O}$. The organic layers were combined, washed with brine, dried over $\mathrm{MgSO}_{4}$, filtered, and concentrated to afford 2 as a colorless oil (yield $2.1 \mathrm{~g}, 92 \%$ ). ${ }^{1} \mathrm{H}$ NMR $\left(200 \mathrm{MHz}, \mathrm{CDCl}_{3}\right): \delta 0.29\left(\mathrm{~s}, J_{\mathrm{Sn}-\mathrm{H}}=27.2 \mathrm{~Hz}, 9 \mathrm{H}, \mathrm{Sn}-\right.$ $\left.\left(\mathrm{CH}_{3}\right)_{3}\right), 2.31\left(\mathrm{~s}, 12 \mathrm{H}, \mathrm{NCH}_{3}\right), 3.54\left(\mathrm{~s}, 4 \mathrm{H}, \mathrm{NCH}_{2}\right), 7.39(\mathrm{~s}, 2 \mathrm{H}$, $\mathrm{ArH}) .{ }^{13} \mathrm{C} \mathrm{NMR}\left(75 \mathrm{MHz}, \mathrm{CDCl}_{3}\right): \delta-9.3\left({ }^{1} J_{\mathrm{SnC}}=337\right.$ and 352 $\left.\mathrm{Hz}, \mathrm{Sn}\left(\mathrm{CH}_{3}\right)_{3}\right), 45.5\left(\mathrm{NCH}_{3}\right), 63.9\left(\mathrm{CH}_{2}\right), 128.1,136.8\left({ }^{2} J_{\mathrm{SnC}}=40\right.$

(34) Beurskens, P. T.; Admiraal, G.; Beurskens, G.; Bosman, W. P.; GarciaGranda, S.; Gould, R. O.; Smits, J. M. M.; Smykalla, C. The DIRDIF99 Program System; Technical Report of the Crystallography Laboratory, University of Nijmegen: Nijmegen, The Netherlands, 1999.

(35) Sheldrick, G. M. SHELXL-97, Program for Crystal Structure Refinement; University of Göttingen: Göttingen, Germany, 1997.

(36) Spek, A. L. J. Appl. Crystallogr. 2003, 36, 7.
$\mathrm{Hz}, \mathrm{ArH}), 137.6\left({ }^{2} J_{\mathrm{SnC}}=45 \mathrm{~Hz}\right), 140.3\left({ }^{1} J_{\mathrm{SnC}}=430\right.$ and $\left.451 \mathrm{~Hz}\right)$. Anal. Calcd for $\mathrm{C}_{15} \mathrm{H}_{27} \mathrm{BrN}_{2} \mathrm{Sn}$ : C, 41.51; H, 6.27. Found: C, 41.15; H, 6.00 .

$4^{\prime}-\left\{4-\mathrm{BrC}_{6} \mathrm{H}_{2}\left(\mathrm{CH}_{2} \mathrm{NMe}_{2}\right)_{2}-3,5\right\}-2,2^{\prime}: 6^{\prime}, 2^{\prime \prime}$-tpy [TPBr] (3). 4'Triflato-2,2':6', $2^{\prime \prime}$-terpyridine (1.50 g, $\left.3.93 \mathrm{mmol}\right), 2$ (2.15 g, 4.96 $\mathrm{mmol}),\left[\mathrm{PdCl}_{2}\left(\mathrm{PPh}_{3}\right)_{2}\right](0.11 \mathrm{~g}, 0.16 \mathrm{mmol})$, and dried $\mathrm{LiCl}(0.53$ $\mathrm{g}, 12.59 \mathrm{mmol})$ were refluxed in dry toluene $(50 \mathrm{~mL})$ for $20 \mathrm{~h}$ in a $100 \mathrm{~mL}$ round-bottom flask under a nitrogen atmosphere. Subsequently, the solvent was removed in vacuo, and the residue was redissolved in $\mathrm{CH}_{2} \mathrm{Cl}_{2}$. The $\mathrm{CH}_{2} \mathrm{Cl}_{2}$ solution was washed with water, filtered over Celite, and dried over $\mathrm{MgSO}_{4}$. After removal of the solvent, the residue was purified via silica gel chromatography using ethyl acetate-hexane $(1: 1 \mathrm{v} / \mathrm{v})$ as the eluent to afford pure 3 as a light yellow solid (yield $0.71, \mathrm{~g} 45 \%$ ), mp $157{ }^{\circ} \mathrm{C} .{ }^{1} \mathrm{H}$ NMR $\left(300 \mathrm{MHz}, \mathrm{CDCl}_{3}\right): \delta 2.37\left(\mathrm{~s}, 12 \mathrm{H}, \mathrm{NCH}_{3}\right), 3.70\left(\mathrm{~s}, 4 \mathrm{H}, \mathrm{NCH}_{2}\right)$, $7.35\left(\mathrm{dd}, J_{\mathrm{HH}}=12.0,0,9 \mathrm{~Hz}, 2 \mathrm{H}, \operatorname{PyrH}\left(5,5^{\prime \prime}\right)\right), 7.85$ (s, 2H, ArH), $7.88\left(\mathrm{td}, J_{\mathrm{HH}}=7.51,1.61 \mathrm{~Hz}, 2 \mathrm{H}, \operatorname{PyrH}\left(4,4^{\prime \prime}\right)\right), 8.66\left(\mathrm{~d}, J_{\mathrm{HH}}=\right.$ $\left.7.9 \mathrm{~Hz}, 2 \mathrm{H}, \operatorname{PyrH}\left(3,3^{\prime \prime}\right)\right), 8.70$ (s, 2H, $\left.\operatorname{PyrH}\left(3^{\prime}, 5^{\prime}\right)\right), 8.73$ (d, $J_{\mathrm{HH}}$ $\left.=4.3 \mathrm{~Hz}, 2 \mathrm{H}, \mathrm{PyrH}\left(6,6{ }^{\prime \prime}\right)\right) .{ }^{13} \mathrm{C} \mathrm{NMR}\left(75 \mathrm{MHz}, \mathrm{CDCl}_{3}\right): \delta 45.5$ $\left(\mathrm{NCH}_{3}\right), 63.8\left(\mathrm{NCH}_{2}\right), 119.1,121.5,123.8,128.2,128.7,136.9$, 137.5, 139.1, 149.1, 149.7, 156.0, 156.2. Anal. Calcd for $\mathrm{C}_{27} \mathrm{H}_{28}$ $\mathrm{BrN}_{5}$ : C, 64.54; H, 5.62; N, 13.94. Found: C, 64.46; H, 5.58; N, 13.91.

[PdBr(TP)] (4a). A mixture of $\mathbf{3}(0.34 \mathrm{~g}, 0.68 \mathrm{mmol})$ and $\left[\mathrm{Pd}_{2-}\right.$ $\left.(\mathrm{dba})_{3}\right] \cdot \mathrm{CHCl}_{3}(0.35 \mathrm{~g}, 0.34 \mathrm{mmol})$ was refluxed in dry benzene $(20 \mathrm{~mL})$ for $2 \mathrm{~h}$. The solvent was evaporated in vacuo, and the obtained residue was dissolved in $\mathrm{CH}_{2} \mathrm{Cl}_{2}$. Addition of $\mathrm{Et}_{2} \mathrm{O}$ caused the precipitation of a yellow powder that was collected by centrifugation, washed several times with $\mathrm{Et}_{2} \mathrm{O}$, and dried in vacuo. Yellow crystals suitable for $\mathrm{X}$-ray analysis were grown by slow diffusion of $\mathrm{Et}_{2} \mathrm{O}$ into a $\mathrm{CH}_{2} \mathrm{Cl}_{2}$ solution of $\mathbf{3 a}$ (yield $0.28 \mathrm{~g}, 68 \%$ ). ${ }^{1} \mathrm{H}$ NMR $\left(300 \mathrm{MHz}, \mathrm{CDCl}_{3}\right): \delta 3.02\left(\mathrm{~s}, 12 \mathrm{H}, \mathrm{NCH}_{3}\right), 4.09(\mathrm{~s}, 4 \mathrm{H}$, $\mathrm{NCH}_{2}$ ), 7.34 (s, 2H, ArH), 7.36 (ddd, $J_{\mathrm{HH}}=7.5,4.8,1.2 \mathrm{~Hz}, 2 \mathrm{H}$, $\operatorname{Pyr}\left(5,5^{\prime \prime}\right), 7.87\left(\mathrm{td}, J_{\mathrm{HH}}=7.8,1.8 \mathrm{~Hz}, 2 \mathrm{H}, \operatorname{Pyr}\left(4,4^{\prime \prime}\right)\right), 8.64(\mathrm{~s}$, 2H, $\left.\operatorname{Pyr}\left(3^{\prime}, 5^{\prime}\right)\right), 8.06\left(\mathrm{~d}, J_{\mathrm{HH}}=7.8 \mathrm{~Hz}, 2 \mathrm{H}, \operatorname{Pyr}\left(3,3^{\prime \prime}\right)\right), 8.71(\mathrm{~d}$, $\left.J_{\mathrm{HH}}=4.8 \mathrm{~Hz}, 2 \mathrm{H}, \operatorname{Pyr}\left(6,6^{\prime \prime}\right)\right),{ }^{13} \mathrm{C} \mathrm{NMR}\left(75 \mathrm{MHz}, \mathrm{CDCl}_{3}\right) \delta 53.8$ $\left(\mathrm{NCH}_{3}\right), 74.5\left(\mathrm{NCH}_{2}\right), 118.5,119.0,121.4,123.9,135.4,136.9$, 145.6, 149.1, 150.6, 155.7, 156.2, 159.4; Anal. Calcd for $\mathrm{C}_{27} \mathrm{H}_{28}$ BrN $_{5}$ Pd: C, 53.26; H, 4.64; N, 11.50. Found: C, 53.20; H, 4.73; $\mathrm{N}, 11.38$.

[TPPdCl] (4b). A solution of $\mathbf{4 a}(0.230 \mathrm{~g}, 0.38 \mathrm{mmol})$ and $\mathrm{Me}_{3}-$ SiOTf $(0.088 \mathrm{~g}, 0.45 \mathrm{mmol})$ in $\mathrm{CH}_{2} \mathrm{Cl}_{2}$ was stirred at room temperature for $30 \mathrm{~min}$. The solvent was evaporated in vacuo, and the solid residue obtained was redissolved in acetone. An excess of $\mathrm{NaCl}$ was added, and the resulting suspension was stirred overnight at room temperature. The solvent was removed in vacuo, and the collected solid residue was dissolved in $\mathrm{CHCl}_{3}$. The organic layer was washed with water and acetone and then dried in vacuo, yielding $\mathbf{4 b}$ as a yellow solid that was separated by centrifugation, washed with water and $\mathrm{Et}_{2} \mathrm{O}$, and dried in vacuo (yield $0.120 \mathrm{~g}$, $71 \%$ ). The NMR data of complex $\mathbf{4 b}$ are identical to those reported for complex $4 \mathbf{a}$.

[Ru(TPBr)(tpy)](PF $\mathbf{P}_{\mathbf{6}} \mathbf{2}_{\mathbf{2}} \mathbf{( 5 )}$. The brown suspension obtained by adding together 3 (50 mg, $0.10 \mathrm{mmol}$ ), [RuCl 3 (tpy)] (44 mg, 0.10 mmol), and 4 drops of $N$-ethylmorpholine in $\mathrm{MeOH}(15 \mathrm{~mL})$ was degassed on a Schlenk line and subsequently refluxed for $75 \mathrm{~min}$. The resulting deep red mixture was filtered over Celite, and the solvent was removed in vacuo. The residue obtained was washed with acetone and $\mathrm{CH}_{2} \mathrm{Cl}_{2}$ and dissolved in $\mathrm{MeOH}(5 \mathrm{~mL})$. A saturated solution of $\mathrm{NaPF}_{6}$ in $\mathrm{MeOH}$ was added, resulting in the precipitation of $\mathbf{5}$ as a red powder that was collected by filtration, washed with cold acetone, and dried in vacuo (yield $65 \mathrm{mg}, 61 \%$ ). ${ }^{1} \mathrm{H}$ NMR (300 MHz, $\left.\mathrm{CD}_{3} \mathrm{COCD}_{3}\right): \delta 2.39\left(\mathrm{~s}, 12 \mathrm{H}, \mathrm{NCH}_{3}\right), 3.76$ 
(s, 4H, $\mathrm{NCH}_{2}$ ), $7.31-7.37$ (m, 4H, PyrA(5, 5") $\left.\operatorname{PyrB}\left(5,5^{\prime \prime}\right)\right), 7.73$ $\left(\mathrm{d}, J_{\mathrm{HH}}=4.9 \mathrm{~Hz}, 2 \mathrm{H}, \operatorname{PyrB}\left(6,6^{\prime \prime}\right)\right), 7.82\left(\mathrm{~d}, J_{\mathrm{HH}}=5.5 \mathrm{~Hz}, 2 \mathrm{H}\right.$, $\left.\operatorname{PyrA}\left(6,6^{\prime \prime}\right)\right), 8.09$ (t, $J_{\mathrm{HH}}=7.9 \mathrm{~Hz}, 4 \mathrm{H}, \operatorname{PyrA}\left(4,4^{\prime \prime}\right)$ and $\operatorname{PyrB}(4$, $\left.\left.4^{\prime \prime}\right)\right), 8.24$ (s, 2H, ArH), 8.59 (t, $\left.J_{\mathrm{HH}}=8.1 \mathrm{~Hz}, 1 \mathrm{H}, \operatorname{PyrA}\left(4^{\prime}\right)\right), 8.82$ $\left(\mathrm{d}, J_{\mathrm{HH}}=7.2 \mathrm{~Hz}, 2 \mathrm{H}, \operatorname{PyrB}\left(3,3^{\prime \prime}\right)\right), 8.95\left(\mathrm{~d}, J_{\mathrm{HH}}=7.8 \mathrm{~Hz}, 2 \mathrm{H}\right.$, $\left.\operatorname{PyrA}\left(3,3^{\prime \prime}\right)\right), 9.08\left(\mathrm{~d}, J_{\mathrm{HH}}=8.1 \mathrm{~Hz}, 2 \mathrm{H}, \operatorname{PyrA}\left(3^{\prime}, 5^{\prime}\right)\right), 9.35$ (s, $\left.2 \mathrm{H}, \mathrm{PyrB}\left(3^{\prime}, 5^{\prime}\right)\right) .{ }^{13} \mathrm{C} \mathrm{NMR}\left(75 \mathrm{MHz}, \mathrm{CD}_{3} \mathrm{COCD}_{3}\right) \delta 46.0\left(\mathrm{NCH}_{3}\right)$, $64.5\left(\mathrm{NCH}_{2}\right), 122.8,125.0,125.6,125.8,128.7,128.8,129.5,129.7$, 137.0, 137.2, 139.2, 139.3, 141.6, 149.0, 153.6, 153.7, 156.6, 156.8, 159.3, 159.4. Anal. Calcd for $\mathrm{C}_{42} \mathrm{H}_{39} \mathrm{BrF}_{12} \mathrm{~N}_{8} \mathrm{P}_{2} \mathrm{Ru}: \mathrm{C}, 44.77 ; \mathrm{H}$, 3.49; N, 9.94. Found: C, 44.58; H, 3.34; N, 9.76.

$\left[\mathbf{R u}(\mathrm{TPBr})_{2}\right]\left(\mathbf{P F}_{\mathbf{6}}\right)_{\mathbf{2}}(\mathbf{6})$. The solution obtained by adding together 3 (120 mg, $0.24 \mathrm{mmol}), \mathrm{RuCl}_{3} \cdot 3 \mathrm{H}_{2} \mathrm{O}$ (50 mg, $0.24 \mathrm{mmol}$ ), and a few drops of $\mathrm{Et}_{3} \mathrm{~N}$ in $\mathrm{EtOH}(15 \mathrm{~mL})$ was degassed on a Schlenk line. The resulting mixture, which rapidly turned brown-red upon heating, was stirred at reflux temperature for $1 \mathrm{~h}$. After the hot mixture was filtered, the solvent was removed in vacuo. The brown solid obtained was washed with water and $\mathrm{CH}_{2} \mathrm{Cl}_{2}$ until the eluent remained colorless. Subsequently, the brown solid was refluxed in $\mathrm{MeOH}(15 \mathrm{~mL})$ with a second equivalent of $3(120 \mathrm{mg}, 0.24 \mathrm{mmol})$ and a few drops of $N$-ethylmorpholine in $\mathrm{MeOH}$ for $1.5 \mathrm{~h}$. The brown solution turned to red upon heating. The solvent was evaporated in vacuo, and the obtained red residue was washed with acetone and dissolved in $\mathrm{MeOH}$. Addition of a saturated aqueous solution of $\mathrm{NaPF}_{6}$ resulted in the precipitation of $\mathbf{6}$ as a red powder that was collected by filtration, washed with cold acetone, and dried in vacuo (yield $212 \mathrm{mg}, 63 \%$ ). ${ }^{1} \mathrm{H}$ NMR (300 MHz, $\mathrm{CD}_{3} \mathrm{COCD}_{3}$ ): $\delta 2.39\left(\mathrm{~s}, 24 \mathrm{H}, \mathrm{NCH}_{3}\right), 3.76\left(\mathrm{~s}, 8 \mathrm{H}, \mathrm{NCH}_{2}\right), 7.34$ (ddd, $J_{\mathrm{HH}}=7.5$, 5.4, $\left.1.5 \mathrm{~Hz}, 4 \mathrm{H}, \operatorname{Pyr}\left(5,5^{\prime \prime}\right)\right), 7.83\left(\mathrm{~d}, J_{\mathrm{HH}}=5.4 \mathrm{~Hz}, 4 \mathrm{H}, \operatorname{Pyr}(6\right.$, $\left.\left.6^{\prime \prime}\right)\right), 8.10\left(\mathrm{td}, J_{\mathrm{HH}}=7.5,1.5 \mathrm{~Hz}, 4 \mathrm{H}, \operatorname{Pyr}\left(4,4^{\prime \prime}\right)\right), 8.24(\mathrm{~s}, 4 \mathrm{H}$, $\mathrm{ArH}), 8.96\left(\mathrm{~d}, J_{\mathrm{HH}}=8.1 \mathrm{~Hz}, 4 \mathrm{H}, \operatorname{Pyr}\left(3,3^{\prime \prime}\right)\right), 9.35$ (s, 4H, Pyr(3', $\left.\left.5^{\prime \prime}\right)\right) .{ }^{13} \mathrm{C}$ NMR $\left(75 \mathrm{MHz}, \mathrm{CD}_{3} \mathrm{COCD}_{3}\right): \delta 46.0\left(\mathrm{NCH}_{3}\right), 64.5$ $\left(\mathrm{NCH}_{2}\right), 122.9,125.8,128.8,129.6,129.7,137.0,139.2,141.6$, 149.0, 153.7, 156.8, 159.4. Anal. Calcd for $\mathrm{C}_{54} \mathrm{H}_{56} \mathrm{Br}_{2} \mathrm{~F}_{12} \mathrm{~N}_{10} \mathrm{P}_{2} \mathrm{Ru}$ : C, 46.46; H, 4.04; N, 10.03. Found: C, 46.40; H, 3.94; N, 9.97.

[Ru(TPPdCl)(tpy)](PF $)_{\mathbf{6}}$ (7). A brown suspension of $\mathbf{3}$ (111 $\mathrm{mg}, 0.19 \mathrm{mmol}),\left[\mathrm{RuCl}_{3}(\mathrm{tpy})\right](86 \mathrm{mg}, 0.19 \mathrm{mmol})$ and 4 drops of $\mathrm{N}$-ethylmorpholine in $\mathrm{MeOH}(15 \mathrm{~mL})$ was degassed on a Schlenk line and subsequently refluxed for $1 \mathrm{~h}$. The mixture, which turned deep red upon heating, was then filtered over Celite, and all volatiles were removed in vacuo. The residue obtained was washed with acetone and dissolved in $\mathrm{MeOH}(5 \mathrm{~mL})$. A saturated aqueous solution of $\mathrm{NaPF}_{6}$ was added, resulting in the precipitation of 7 as a red powder; it was collected by filtration, washed with cold acetone, and dried in vacuo (yield $100 \mathrm{mg}, 39 \%$ ). ${ }^{1} \mathrm{H}$ NMR (300 $\mathrm{MHz}, \mathrm{CD}_{3} \mathrm{CN}$ ): $\delta 3.00\left(\mathrm{~s}, 12 \mathrm{H}, \mathrm{NCH}_{3}\right), 4.30\left(\mathrm{~s}, 4 \mathrm{H}, \mathrm{NCH}_{2}\right), 7.15-$ $7.20\left(\mathrm{~m}, 4 \mathrm{H}, \operatorname{PyrA}\left(5,5^{\prime \prime}\right), \operatorname{PyrB}\left(5,5^{\prime \prime}\right)\right), 7.35\left(\mathrm{~d}, J_{\mathrm{HH}}=4.9 \mathrm{~Hz}\right.$, $\left.2 \mathrm{H}, \operatorname{PyrB}\left(6,6^{\prime \prime}\right)\right), 7.42\left(\mathrm{~d}, J_{\mathrm{HH}}=4.9 \mathrm{~Hz}, 2 \mathrm{H}, \operatorname{PyrA}\left(6,6^{\prime \prime}\right)\right), 7.70$ (s, 2H, ArH), 7.90-7.97 (m, 4H, PyrA(4, 4"), PyrB(4, 4")), 8.42 $\left(\mathrm{t}, J_{\mathrm{HH}}=8.1 \mathrm{~Hz}, 1 \mathrm{H}, \operatorname{PyrA}\left(4^{\prime}\right)\right), 8.50\left(\mathrm{~d}, J_{\mathrm{HH}}=8.1 \mathrm{~Hz}, 2 \mathrm{H}\right.$, PyrB$\left.\left(3,3^{\prime \prime}\right)\right), 8.61\left(\mathrm{~d}, J_{\mathrm{HH}}=8.1 \mathrm{~Hz}, 2 \mathrm{H}, \operatorname{PyrA}\left(3,3^{\prime \prime}\right)\right), 8.76\left(\mathrm{~d}, J_{\mathrm{HH}}=\right.$ $\left.8.1 \mathrm{~Hz}, 2 \mathrm{H}, \operatorname{PyrA}\left(3^{\prime}, 5^{\prime}\right)\right), 9.35$ (s, 2H, PyrB $\left.\left(3^{\prime}, 5^{\prime}\right)\right) .{ }^{13} \mathrm{C}$ NMR $(75$ $\left.\mathrm{MHz}, \mathrm{CD}_{3} \mathrm{CN}\right): \delta 53.1\left(\mathrm{NCH}_{3}\right), 74.5\left(\mathrm{NCH}_{2}\right), 120.2,121.9,124.4$, $125.1(2 \times), 128.1,128.2,134.5,136.4,138.7,138.8,148.3,149.5$, 153.0, 153.2, 156.0, 156.2, 158.8, 158.9. Anal. Calcd for $\mathrm{C}_{42} \mathrm{H}_{39^{-}}$ $\mathrm{ClF}_{12} \mathrm{~N}_{8} \mathrm{P}_{2} \mathrm{PdRu}: \mathrm{C}, 42.44 ; \mathrm{H}, 3.31 ; \mathrm{N}, 9.43$. Found: $\mathrm{C}, 42.59 ; \mathrm{H}$, $3.46 ; \mathrm{N}, 9.29$.
[Ru(TPPdCl $\left.)_{2}\right]\left(\mathbf{P F}_{6}\right)_{2}(\mathbf{8})$. A solution of $\mathbf{4 b}(54 \mathrm{mg}, 0.10 \mathrm{mmol})$ and $\left[\mathrm{RuCl}_{3} \cdot 3 \mathrm{H}_{2} \mathrm{O}\right](20 \mathrm{mg}, 0.10 \mathrm{mmol})$ in $\mathrm{EtOH}(10 \mathrm{~mL})$ was degassed in a Schlenk line and subsequently refluxed for $1 \mathrm{~h}$. The solvent was then removed in vacuo. The resulting brown-red residue was collected by filtration; washed with $\mathrm{EtOH}$, water, and $\mathrm{Et}_{2} \mathrm{O}$; and dried in air. Subsequently, the brown solid was refluxed with a second equivalent of $\mathbf{4 b}(54 \mathrm{mg}, 0.10 \mathrm{mmol})$ and a few drops of $\mathrm{N}$-ethylmorpholine in $\mathrm{MeOH}(10 \mathrm{~mL})$ for $1.5 \mathrm{~h}$. The brown solution turned red upon heating. The solvent was removed in vacuo. The red solid obtained was collected by filtration and washed with acetone and $\mathrm{CH}_{2} \mathrm{Cl}_{2}$. The resulting chlorine complex was then dissolved in $\mathrm{MeOH}(20 \mathrm{~mL})$. Next, an excess of methanolic $\mathrm{NaPF}_{6}$ was added, yielding $\mathbf{8}$ as a red solid that was collected by filtration, washed with cold acetone and $\mathrm{CH}_{2} \mathrm{Cl}_{2}$, and dried in vacuo (yield $99 \mathrm{mg}, 70 \%) .{ }^{1} \mathrm{H}$ NMR (300 MHz, $\left.\mathrm{CD}_{3} \mathrm{OD}\right): \delta 3.01\left(\mathrm{~s}, 12 \mathrm{H}, \mathrm{NCH}_{3}\right.$ ), $4.32\left(\mathrm{~s}, 4 \mathrm{H}, \mathrm{NCH}_{2}\right), 7.28\left(\mathrm{t}, J_{\mathrm{HH}}=6.3 \mathrm{~Hz}, 2 \mathrm{H}, \operatorname{Pyr}\left(5,5^{\prime \prime}\right)\right), 7.53$ $\left(\mathrm{d}, J_{\mathrm{HH}}=5.2 \mathrm{~Hz}, 2 \mathrm{H}, \operatorname{Pyr}\left(6,6^{\prime \prime}\right)\right), 7.80\left(\mathrm{t}, J_{\mathrm{HH}}=7.9 \mathrm{~Hz}, 2 \mathrm{H}, \mathrm{Pyr}-\right.$ $\left.\left(4,4^{\prime \prime}\right)\right), 8.24$ (s, 2H, ArH), 8.88 (d, $\left.J_{\mathrm{HH}}=7.3 \mathrm{~Hz}, 2 \mathrm{H}, \operatorname{Pyr}\left(3,3^{\prime \prime}\right)\right)$, 9.21 (s, 2H, Pyr( $\left.\left.3^{\prime}, 5^{\prime}\right)\right) .{ }^{13} \mathrm{C} \mathrm{NMR}\left(75 \mathrm{MHz}, \mathrm{CD}_{3} \mathrm{COCD}_{3}\right): \delta 53.4$ $\left(\mathrm{NCH}_{3}\right), 75.0\left(\mathrm{NCH}_{2}\right), 120.4,122.1,125.4,128.4,129.3,139.0$, 148.5, 153.4, 156.4, 159.3, 163.25, 169.28. ESI-MS: $\mathrm{m} / \mathrm{z} 615.04$ $\left(\left[\mathrm{M}-2 \mathrm{PF}_{6}\right]^{2+}\right)$.

[Ru(TPPdSCN)(tpy)](PF $\left.)_{\mathbf{6}}\right)_{\mathbf{2}}$ (10). A solution of 7 (57 mg, 0.05 mmol) in dry $\mathrm{CH}_{2} \mathrm{Cl}_{2}(20 \mathrm{~mL})$ was added under nitrogen and exclusion of light to a Schlenk vessel containing $\mathrm{AgSCN}(8.3 \mathrm{mg}$, $0.05 \mathrm{mmol})$ dissolved in dry $\mathrm{CH}_{2} \mathrm{Cl}_{2}(5 \mathrm{~mL})$. The mixture was stirred at room temperature for $5 \mathrm{~h}$. Subsequently, $\mathrm{AgCl}$ was filtered off over Celite, and all volatiles were removed in vacuo to afford 15 as a red powder (yield $58 \mathrm{mg}, 95 \%) .{ }^{1} \mathrm{H}$ NMR $\left(300 \mathrm{MHz}, \mathrm{CD}_{3-}\right.$ $\left.\mathrm{COCD}_{3}\right): \delta 3.03\left(\mathrm{~s}, 12 \mathrm{H}, \mathrm{NCH}_{3}\right), 4.37\left(\mathrm{~s}, 4 \mathrm{H}, \mathrm{NCH}_{2}\right), 7.35-7.29$ $\left(\mathrm{m}, 4 \mathrm{H}, \operatorname{PyrA}\left(5,5^{\prime \prime}\right), \operatorname{PyrB}\left(5,5^{\prime \prime}\right)\right), 7.69\left(\mathrm{~d}, J_{\mathrm{HH}}=4.5 \mathrm{~Hz}, 2 \mathrm{H}\right.$, $\left.\operatorname{PyrB}\left(6,66^{\prime \prime}\right)\right), 7.77$ (d, $\left.J_{\mathrm{HH}}=4.8 \mathrm{~Hz}, 2 \mathrm{H}, \operatorname{PyrA}\left(6,66^{\prime \prime}\right)\right), 7.84$ (s, 2H, ArH), 8.10-8.02 (m, 4H, PyrA(4, 4"), PyrB(4, 4")), 8.57 (t, $\left.J_{\mathrm{HH}}=8.1 \mathrm{~Hz}, 1 \mathrm{H}, \operatorname{PyrA}\left(4^{\prime}\right)\right), 8.81\left(\mathrm{~d}, J_{\mathrm{HH}}=8.1 \mathrm{~Hz}, 2 \mathrm{H}, \operatorname{PyrB}(3\right.$, $\left.\left.3^{\prime \prime}\right)\right), 8.95\left(\mathrm{~d}, J_{\mathrm{HH}}=8.1 \mathrm{~Hz}, 2 \mathrm{H}, \operatorname{PyrA}\left(3,3^{\prime \prime}\right)\right), 8.76\left(\mathrm{~d}, J_{\mathrm{HH}}=8.1\right.$ $\left.\mathrm{Hz}, 2 \mathrm{H}, \operatorname{PyrA}\left(3^{\prime}, 5^{\prime}\right)\right), 9.07$ (s, 2H, PyrB(3', 5')). ${ }^{13} \mathrm{C}$ NMR (75 $\left.\mathrm{MHz}, \mathrm{CD}_{3} \mathrm{COCD}_{3}\right): \delta 52.6\left(\mathrm{NCH}_{3}\right), 74.4\left(\mathrm{NCH}_{2}\right), 120.2,122.0$, 124.8, $125.5(2 \times), 128.6,128.7,134.7,136.9,138.0,139.0,148.3$, 149.5, 150.0, 153.4, 156.5, 156.9, 159.4. IR (Nujol, PrCN): $v$ $(\mathrm{SCN})=2080 \mathrm{~cm}^{-1}$. ESI-MS: $\mathrm{m} / \mathrm{z} 460.07\left(\left[\mathrm{M}-2 \mathrm{PF}_{6}\right]^{2+}\right) ; 1066.19$ $\left(\left[\mathrm{M}-\mathrm{PF}_{6}\right]^{+}\right)$.

Acknowledgment. The authors kindly acknowledge A. D'Aleo for his assistance during lifetime measurements performed at room temperature. This work was supported by the Council for Chemical Sciences from the Dutch Organization of Scientific Research (NWO). The authors thank NWO/NCF for the use of supercomputer time on TERAS/ASTER, SARA (The Netherlands, Project SG-032). R.W.A.H. acknowledges financial support from the NWO Grant 700.53.401.

Supporting Information Available: Cif files of crystal data collection and refinement parameters, atomic coordinates, bond lengths and angles, anisotropic displacement parameters for complexes $4 \mathbf{a}$ and $\mathbf{6}$. This material is available free of charge via Internet at http://pubs.acs.org.

IC051967C 